\title{
Silicon cycle in Indian estuaries and its control by biogeochemical and anthropogenic processes
}

\author{
K.R. Mangalaa ${ }^{a}$, D. Cardinal $^{\mathrm{a}, *}$, J. Brajard ${ }^{\mathrm{a}}$, D.B. Rao ${ }^{\mathrm{b}}$, N.S. Sarma ${ }^{\mathrm{b}}$, I. Djouraev ${ }^{\mathrm{a}}$, G. Chiranjeevulu ${ }^{\mathrm{b}}$, \\ K. Narasimha Murty ${ }^{b}$, V.V.S.S. Sarma ${ }^{c}$ \\ a Sorbonne Universités (UPMC, Univ. Paris 06)-CNRS-IRD-MNHN, LOCEAN Laboratory, CP100, 4 place Jussieu, F-75252 Paris Cedex 5, France \\ ${ }^{\mathrm{b}}$ Marine Chemistry Laboratory, Andhra University, Visakhapatnam 530003, India \\ ${ }^{c}$ National Institute of Oceanography, Regional Centre, 176 Lawsons Bay Colony, 530017 Visakhapatnam, India
}

\section{A R T I C L E I N F O}

Keywords:

Amorphous silica

Weathering

Diatoms

Land use

Monsoon

Land-to-ocean continuum

\begin{abstract}
A B S T R A C T
We study the silicon biogeochemical cycle and its associated parameters in 24 and 18 Indian estuaries during dry and wet periods respectively. We focus more specifically on dissolved Si (DSi), amorphous Si (ASi,) lithogenic Si (LSi), Particulate Organic Carbon (POC), Total Suspended Material (TSM), Dissolved Inorganic Nitrogen (DIN), salinity and fucoxanthin, a marker pigment for diatoms. Overall, we show that the estuaries have strong inter and intra variability of their biogeochemical parameters both seasonally and along salinity gradients. Based on Principal Component Analysis and clustering of categorised (upper and lower) estuaries, we discuss the four major processes controlling the Si variability of Indian estuaries: 1) lithogenic supply, 2) diatom uptake, 3) mixing of sea water and, 4) land use. The influence of lithogenic control is significantly higher during the wet period than during the dry period, due to a higher particle supply through monsoonal discharge. A significant diatom uptake is only identified in the estuaries during dry period. By taking into account the non-conservative nature of $\mathrm{Si}$ and by extrapolating our results, we estimate the fluxes from the Indian subcontinent of DSi, ASi, LSi to the Bay of Bengal $(211 \pm 32,10 \pm 4.7,2028 \pm 317 \mathrm{Gmol})$ and Arabian Sea ( $80 \pm 15,7 \pm 1.1,1717 \pm 932 \mathrm{Gmol})$. We show the impact of land use in watersheds with higher levels of agricultural activity amplifies the supply of Si to the coastal Bay of Bengal during the wet season. In contrast, forest cover and steep slopes cause less Si supply to the Arabian Sea by restricting erosion when entering the estuary. Finally, Si:N ratios show that nitrogen is always in deficit relative to silicon for diatom growth, these high $\mathrm{Si}: \mathrm{N}$ ratios likely contribute to the prevention of eutrophication in the Indian estuaries and coastal sea.
\end{abstract}

\section{Introduction}

Silicon ( $\mathrm{Si}$ ) constitutes $28 \%$ of the Earth's crust and it is the second most abundant element (Wedepohl, 1995). In aquatic ecosystems, $\mathrm{Si}$ is released through chemical weathering in dissolved form and by erosion as particles with high $\mathrm{Si}$ content either as primary residual minerals (e.g. quartz, feldspars) or as secondary minerals (e.g. clays). This particulate Si mineral pool is referred to as lithogenic silicon (LSi) and it is often neglected in biogeochemical budgets because of its low reactivity. Silicic acid (or dissolved silicon, DSi), is a key nutrient for diatoms, sponges, radiolarians and other aquatic organisms with a siliceous skeleton. Additionally, terrestrial plants take up DSi and precipitate silica particles (called phytoliths) inside cells. Diatoms and phytoliths are considered to be the major source of Biogenic Silica (BSi) supply to the coastal water (Ragueneau et al., 2000). In the ocean, diatoms play a dominant role amongst phytoplankton in carbon uptake (75\% of coastal primary production; Nelson et al., 1995) and sediment burial because of their larger size and refractory structure (Ducklow et al., 2001). Carbon and silicon cycles are thus inter-related since diatoms presently play a dominant role in carbon sequestration whereas weathering connects $\mathrm{C}$ and $\mathrm{Si}$ cycles at long-term geological cycles (Berner, 1992).

Today, $6.2 \pm 1.8 \mathrm{Tmol} \mathrm{yr}^{-1}$ of DSi and $1.1 \pm 0.2 \mathrm{Tmol} \mathrm{yr}^{-1}$ of BSi are transported by rivers to the estuaries (Tréguer and De La Rocha, 2013). The amorphous silica (ASi) is mostly of biogenic origin (phytoliths, diatoms, sponge spicules) and relatively dissolvable in the aquatic ecosystems. ASi or BSi transport through rivers has often been

\footnotetext{
* Corresponding author.

Email address: damien.cardinal@upmc.fr (D. Cardinal)
} 
neglected compared to DSi, but some studies clearly show a substantial contribution of ASi flux to the ocean (e.g. Conley, 1997). For instance, in some rivers, ASi flux can exceed 50\% of DSi flux (Frings et al., 2014) and may thereby significantly contribute to the global Si cycle. Phytoliths can also contribute significantly to the BSi pool in rivers (Cary et al., 2005; Ran et al., 2015). According to the revised oceanic silicon cycle (Tréguer and De La Rocha, 2013), and neglecting LSi, 80\% of external Si supply to the ocean is coming from rivers either as ASi or DSi. About $21 \%\left(1.5 \pm 0.5 \mathrm{Tmol} \mathrm{Si} \mathrm{yr}^{-1}\right)$ is trapped in the estuaries, yielding a net supply of $5.8 \pm 1.9 \mathrm{Tmol} \mathrm{Si} \mathrm{yr}^{-1}$ to the ocean (Tréguer and De La Rocha, 2013). One can notice that there exist large uncertainties regarding the above fluxes (ca. $\pm 33 \%$ ) due to the poor understanding of the seasonal cycle of $\mathrm{Si}$ in many rivers and the absence of data, particularly for ASi, as well as the non-conservative behaviour of DSi in the estuaries before entering the coastal region (Conley et al., 1993; Chou and Wollast, 2006; Dürr et al., 2011).

By definition, an estuary is a semi-enclosed coastal body having a open connection with both sea water and fresh water from land drainage up to the tidal freshwater reach. The estuarine ecosystems are highly productive, with a rich biodiversity. They are characterized by profound changes in the hydro-chemical properties and biological processes. Anderson (1986) stated that biological productivity is higher in the tidal freshwater reach because of reduced turbidity (and hence reduction of its limiting effect on light) as opposed to the turbidity maximum region along the increasing salinity gradient. Diatom growth may affect DSi concentration in the estuaries through uptake (Admiraal et al., 1990; Conley, 1997; Hughes et al., 2011). In addition, anthropogenic activities such as damming may decrease DSi by favouring BSi retention in the reservoirs (Conley, 2002; Friedl et al., 2004; Humborg et al., 2006; Laruelle et al., 2009; Hughes et al., 2012). In contrast, deforestation (Conley et al., 2008) and amplified erosion (Xiangbin et al., 2015) may increase the supply of both DSi and BSi to the coastal system. Moreover, heightened fertilizer usage (Li et al., 2007) results in a supply of excess $\mathrm{N}$ and $\mathrm{P}$ over Si leading to the development of non-diatom blooms favouring HAB (Harmful Algal Blooms) and eutrophication, major threats to the base of food chain (Garnier et al., 2010; Howarth et al., 2011).

The eutrophication potential has been increasing for Indian estuaries over the last four decades, compared to the temperate estuaries (Europe and USA), because of increase in agriculture, fast urbanization and insufficient sewage treatment. The ICEP (Indicator of Coastal Eutrophication Potential) is based on the N:Si or P:Si ratios of riverine inputs to the coast (Garnier et al., 2010). A higher ICEP would favour eutrophication since $\mathrm{Si}$ would be limiting. Hence, ignoring the ASi fraction that could dissolve and partly counterbalance the excess of $\mathrm{N}$ and $\mathrm{P}$ relative to $\mathrm{Si}$, may lead to an overestimated eutrophication potential. Compared to N, $\mathrm{P}$ and $\mathrm{C}$, the Si cycle is less well understood and needs to be approached by considering the above processes along the land-ocean continuum for better determination of the health and functioning of the ecosystems. There is a lack of data, especially in the tropical regions, which contribute to $74 \%$ of riverine Si input (Tréguer et al., 1995).

Indian tropical estuaries differ significantly from other estuaries in terms of rainfall, discharge and land use. The Indian subcontinent is rich with high mountain ranges, widespread plateaus and extensive plains traversed by large rivers. India has $\sim 220$ major and minor estuaries with varying size and shape along the $\sim 7500 \mathrm{~km}$ coastline (Sarma et al., 2012; Rao et al., 2013). India experiences seasonally reversing monsoonal systems called southwest or summer monsoon (June to September) and northeast or winter monsoon (November to February). In the Indian subcontinent, $75 \%$ of annual rainfall is received during southwest monsoon and the remaining $25 \%$ during northeast mon- soon (Attri and Tyagi, 2010). Except for the glacial rivers such as Ganges and Brahmaputra, Indian rivers are strongly influenced by the precipitations during southwest and northeast monsoons and most estuaries receive a huge freshwater flux in a limited period of time. These estuaries are therefore referred to as monsoonal estuaries. For instance, southwestern India receives more rainfall $(\sim 3000 \mathrm{~mm} / \mathrm{yr})$ than northeastern (1000-2500 mm/yr), southeastern (300-500 mm/yr) and northwestern India $(200-500 \mathrm{~mm} / \mathrm{yr}$ ) (Soman and Kumar, 1990). The variability of the estuarine discharge induced by rainfall is discussed in Sarma et al. (2014). During the peak monsoon period the entire estuary may be filled with freshwater with no vertical salinity gradient and exhibit riverine and non-steady state behaviour (Vijith et al., 2009; Sridevi et al., 2015). On the other hand, the upper estuary gets dried up due to weak discharge, allowing the penetration of seawater during the dry period. The Indian subcontinent is bounded by the Arabian Sea on the west and the Bay of Bengal on the east and receives $0.3 \times 10^{12} \mathrm{~m}^{3}$ freshwater influx from rivers to the former basin and $1.6 \times 10^{12} \mathrm{~m}^{3}$ to the latter basin (Krishna et al., 2016). In addition to freshwater influx, the glacial and monsoonal rivers supply a enormous load of suspended matter of around $1.4 \times 10^{9}$ t to the Bay of Bengal and $0.2 \times 10^{9}$ t into the Arabian Sea respectively (Nair et al., 1989; Ittekkot et al., 1991).

Agriculture is the main economic activity in India and the most common land use (61\% of total watershed - Central Water Commission Report, 2009), with a massive consumption of fertilizers (it ranks second in the world - Ministry of Agriculture report, 2012-13), which end up in the estuaries and coastal water (Sarma et al., 2014). This may provoke an imbalanced nutrient supply to the coastal waters. Apart from the fertilizer use, agriculture also favours erosion. Around $5.3 \times 10^{9} \mathrm{t}$ of soil is eroded annually, of which $29 \%$ enters the sea, $10 \%$ is retained by reservoirs and the remaining $61 \%$ are displaced without reaching the ocean yet (Ministry of Agriculture report, 2012-13). The rivers in India are heavily dammed to meet irrigation, domestic and hydroelectric demands. India ranks fourth in total number of dams in the world (CWC, 2009) and damming may cause nutrient retention via biological uptake and sedimentation, thereby also altering the nutrient supply and in fine the phytoplankton diversity and production in the estuaries as well as adjacent coastal ocean. However, despite high consumption of fertilizers in the Indian subcontinent, the concentrations and fluxes of DIN and DIP to the coastal waters is much lower than e.g. in the China Sea. This could be caused by a high nutrient supply during the short 2-3 peak monsoon months avoiding eutrophication because of the high turbidity and quick dilution into the ocean (Rao and Sarma, 2013; Krishna et al., 2016) and/or a high Si:N ratios preventing non-diatom blooms (Garnier et al., 2010).

So far, there are no studies on the ASi and LSi distribution in the Indian estuaries other than Ganges (Frings et al., 2014). Here, we will mainly focus on 1) Seasonal variability of ASi, DSi and LSi in ca. 20 estuaries draining into the Bay of Bengal and Arabian Sea. 2) Understanding the associated biogeochemical processes and the impact of land use on Si variability. And, lastly, 3) Estimating the flux of ASi, DSi and LSi from the Indian sub-continent to the North Indian coastal ocean and their contribution to the global Si budget.

\section{Materials and methods}

In this study, the estuaries are first categorized into four groups based on their geographic location: northeast (NE), southeast (SE), southwest (SW), northwest (NW) (Table 1 and details therein). These estuaries were studied before, for dissolved inorganic nitrogen (DIN) fluxes, greenhouse gas fluxes and source of organic matter (Sarma et al., 2012, 2014; Rao and Sarma, 2013; Krishna et al., 2016). 
Table 1

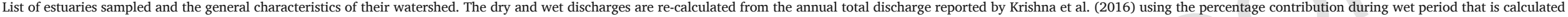

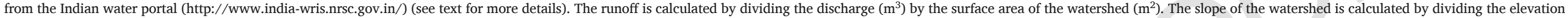
of watershed by the length of the river. Except annual total discharge, all data is obtained from http://www.india-wris.nrsc.gov.in/. For some of the watersheds, the land-use data were grouped for adjacent rivers.

\begin{tabular}{|c|c|c|c|c|c|c|c|c|c|c|}
\hline & Name of River/Estuary & Catchment area & Length & $\%$ Agriculture & $\%$ Forest & Slope & Discharge & Runoff & Discharge & Runoff \\
\hline & & & & & & 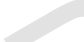 & \multicolumn{2}{|l|}{ Dry period } & \multicolumn{2}{|l|}{ Wet period } \\
\hline & & $\mathrm{km}^{2}$ & $\mathrm{~km}$ & 2005-2006 & & $\%$ & $\mathrm{~km}^{3}$ & $(\mathrm{~m})$ & $\mathrm{km}^{3}$ & $(\mathrm{~m})$ \\
\hline \multicolumn{11}{|c|}{ Rivers flowing in Bay of Bengal, East coast estuaries } \\
\hline & Haldia (Hal) & 10,200 & NA & 65 (Ganges) & 16 (Ganges) & NA & 12.6 & 1.24 & 37 & 3.71 \\
\hline \multirow[t]{6}{*}{ Northeast } & Subernereka (Sub) & 29,196 & 448 & 54 & 29 & 0.13 & 3.1 & 0.11 & 9.3 & 0.32 \\
\hline & Baitharani (Bai) & 10,982 & 355 & 52 & 34 & 0.25 & NA & NA & NA & NA \\
\hline & Mahanadi (Maha) & 141,600 & 851 & 54 & 33 & 0.10 & $16 \pm 0.7$ & 0.12 & $50 \pm 9$ & 0.35 \\
\hline & Rushikulya (Rush) & 7700 & 165 & 60 & 26 & 0.61 & $0.6 \pm 0.4$ & 0.08 & $1.1 \pm 0.3$ & 0.15 \\
\hline & Vamsadhara (Vam) & 10,830 & 254 & $"$ & $"$ & NA & $1.1 \pm 0.1$ & 0.10 & $2.4 \pm 0.8$ & 0.22 \\
\hline & Nagavalli (Nag) & 9510 & 256 & " & $"$ & 0.51 & $0.7 \pm 0.3$ & 0.08 & $1.2 \pm 0.6$ & 0.13 \\
\hline \multirow[t]{8}{*}{ Southeast } & Krishna (Kris) & 258,948 & 1400 & 76 & 10 & 0.10 & $3.6 \pm 0.1$ & 0.01 & $66 \pm 10$ & 0.26 \\
\hline & Godavari (God) & 312,812 & 1465 & 60 & 30 & 0.07 & $21 \pm 1.4$ & 0.07 & $90 \pm 26$ & 0.29 \\
\hline & Penna (pen) & 55,213 & 597 & 59 & 20 & 0.13 & $0.6 \pm 0.005$ & 0.01 & $5.7 \pm 0.7$ & 0.10 \\
\hline & Ponnaiyar (pon) & 16,019 & 292 & 67 & 15 & 0.31 & $0.1 \pm 0.005$ & 0.01 & $1.5 \pm 0.6$ & 0.09 \\
\hline & Vellar (Vel) & 8922 & 210 & $"$ & $"$ & 0.43 & 0.3 & 0.04 & $0.6 \pm 0.1$ & 0.06 \\
\hline & Cauvery (Cau) & 81,155 & 800 & 66 & 21 & 0.17 & $4.3 \pm 0.2$ & 0.05 & $17 \pm 2.1$ & 0.21 \\
\hline & Ambullar (Amb) & NA & NA & 67 & 15 & NA & NA & NA & NA & NA \\
\hline & Vaigai (Vai) & 7741 & 258 & $"$ & $"$ & 0.47 & NA & NA & NA & NA \\
\hline \multicolumn{11}{|c|}{ Rivers flowing in Arabian sea, west coast estuaries } \\
\hline \multirow[t]{7}{*}{ Southwest } & Kochi Backwater (KBW) & 5243 & 228 & 51 & 35 & NA & $5.1 \pm 0.2$ & 0.96 & $7.2 \pm 0.4$ & 1.38 \\
\hline & Chalakudi (cha) & 1704 & 130 & $"$ & $"$ & 0.96 & $0.5 \pm 0.1$ & 0.30 & $1.4 \pm 0.4$ & 0.83 \\
\hline & Bharathapula (Bha) & 5397 & 251 & " & $"$ & 0.98 & $1.7 \pm 0.03$ & 0.32 & $3.3 \pm 0.2$ & 0.62 \\
\hline & Netravathi (Net) & 3657 & 103 & $"$ & $"$ & 0.97 & $1.5 \pm 0.1$ & 0.42 & $9.5 \pm 1.5$ & 2.59 \\
\hline & Kali (Kali) & 4943 & 184 & 44 & 35 & NA & 0.7 & 0.14 & $4.1 \pm 0.7$ & 0.83 \\
\hline & Zuari (Zua) & 1152 & 34 & $"$ & $"$ & NA & 0.6 & 0.48 & $2.7 \pm 0.7$ & 2.34 \\
\hline & Mandovi (Man) & 1895 & 50 & $"$ & $"$ & 1.20 & $0.6 \pm 0.1$ & 0.30 & $2.7 \pm 0.7$ & 1.45 \\
\hline \multirow[t]{4}{*}{ Northwest } & Tapti (Tap) & 65,145 & 724 & 66 & 24 & 0.10 & $5.2 \pm 0.1$ & 0.08 & $9.7 \pm 0.5$ & 0.15 \\
\hline & Narmada (Nar) & 98,796 & 1312 & 57 & 33 & 0.08 & $8.9 \pm 0.5$ & 0.09 & $37 \pm 10$ & 0.37 \\
\hline & Mahisagar (Mahi) & 34,842 & 583 & 64 & 19 & 0.09 & $1.2 \pm 0.03$ & 0.04 & $9.8 \pm 5.4$ & 0.28 \\
\hline & Sabarmathi (Sab) & 21,674 & 371 & 75 & 12 & 0.21 & $0.9 \pm 0.1$ & 0.04 & $2.8 \pm 1.3$ & 0.13 \\
\hline
\end{tabular}




\subsection{Sampling and ancillary biogeochemical parameters}

24 estuaries were sampled along the entire coastline of India during the dry (NE monsoon, Jan-Feb 2012) and 18 during the wet period (SW monsoon, July-August 2014) (Fig. 1). In each estuary, generally three to five samples were collected across the salinity gradient from near-zero salinity to the mouth of the estuary. The mode of sampling was adapted to circumstances such as boat/ferry availability and accessibility (e.g. restricted due to heavy discharge). Some were sampled directly from shore, but most samples were obtained from the middle of the stream (a strategy we have favoured whenever possible). Temperature and salinity were measured by using portable CTD for some estuaries (Sea Bird Electronics, SBE 19 plus, USA) and portable pH and conductivity electrode (WTW, MultiLine P4) were used in other estuaries. The latter was calibrated with CTD to calculate the salinity. Surface water samples were collected for Dissolved Inorganic Nitrogen (DIN), Dissolved Inorganic Phosphorus (DIP), silicic acid (DSi), Total Suspended Material (TSM) and phytoplankton pigments using Niskin (5 L) sampler. The DIP and DIN samples were preserved with saturated mercuric chloride after filtration to stop bacterial activity, and transported to the laboratory for analysis. DIP and DIN were analysed using spectrophotometer following Grasshoff et al. (1999). Depending on the turbidity, $100-500 \mathrm{ml}$ of water was filtered with a cellulose nitrate filter for dry period samples (pore size $0.45 \mu \mathrm{m}$ ) and polyethersulfone Supor $(0.2 \mu \mathrm{m}$, Pall Corporation) filter for wet period. TSM is calculated by subtracting the weight (recorded before sampling) of each filter. Subse- quently, amorphous silica (ASi) is measured from an aliquot of the filter. Another $500 \mathrm{ml}$ of each sample was filtered through Glass Fibre membrane (GF/F; $0.7 \mu \mathrm{m}$ pore size; Whatman) under gentle vacuum, for the measurement of photosynthetic pigments. Phytoplankton pigments are tracers of the type of phytoplankton. Fucoxanthin is a pigment present in the bacillariophyceae group and as such considered indicative for the presence of diatoms (Ansotegui, 2001; Wysocki et al., 2006; Zhang et al., 2015). Fucoxanthin is measured using High Performance Liquid Chromatography (HPLC-series 1200 Agilent Technologies) following Heukelem and Thomas (2001).

\subsection{Water discharge}

The water discharge in Indian estuaries is highly dependant on the monsoonal rainfall and varies between 0.1 and $20 \mathrm{~km}^{3}$ and $0.6-90 \mathrm{~km}^{3}$ during dry (non-monsoon) and wet (monsoon) periods respectively (Table 1). The dry and wet discharges are re-calculated from the annual total discharge reported by Krishna et al. (2016) because their data is closest to our sampling sites. To separate the wet and dry period discharge for each estuary, we calculate their relative contributions using data from the Indian water portal (http://www.india-wris.nrsc.gov.in/ ). As this portal contains no discharge data for the wet sampling period (July-August 2014), 10 years average data for the four monsoon months (June-September for SW monsoonal rivers, September-December for NE monsoonal rivers) as well as 10 years average for the eight remaining low discharge months are used instead.

Large differences in the amount of precipitation, water use, length and origin of the river are responsible for a high regional variability of

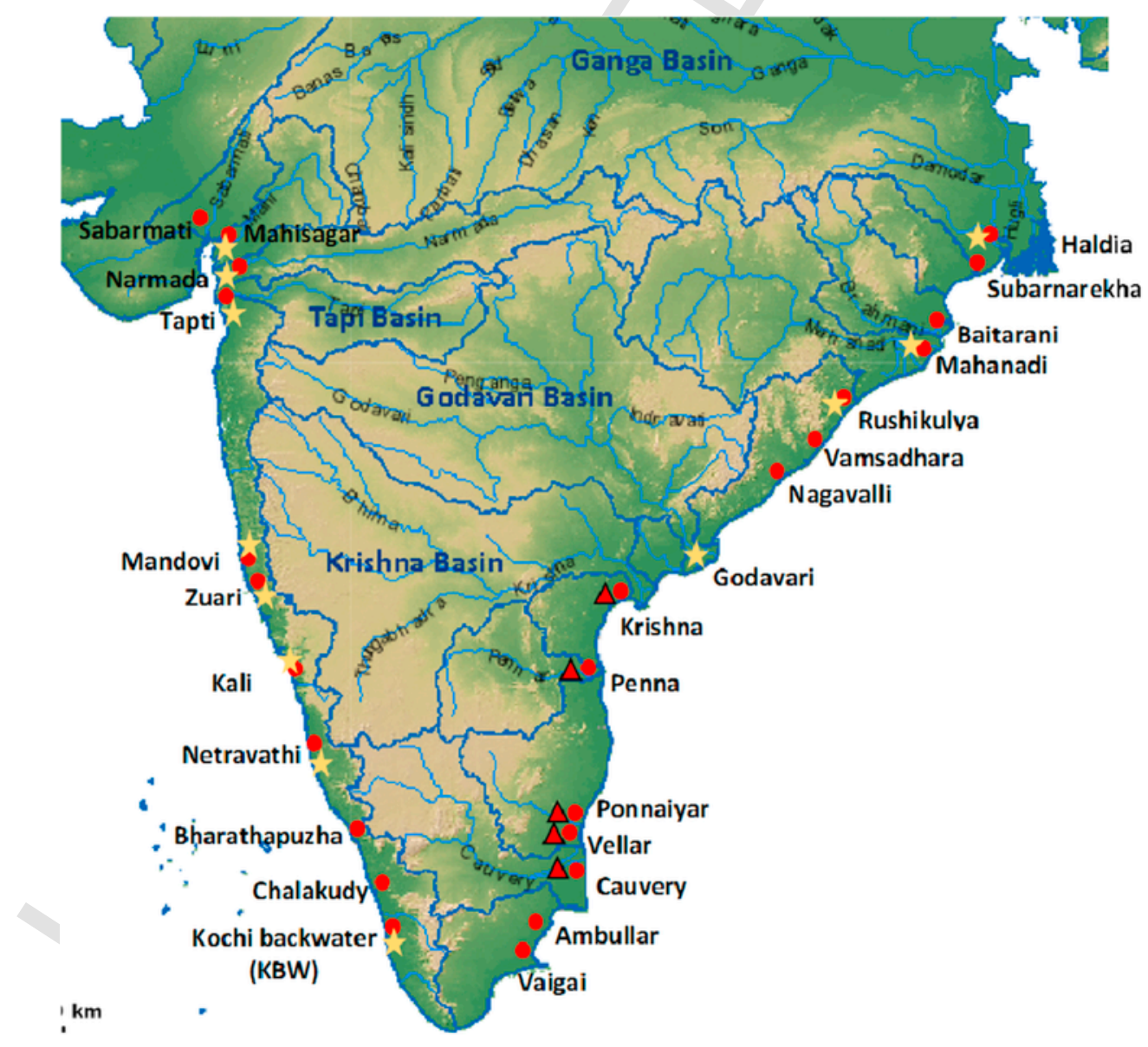

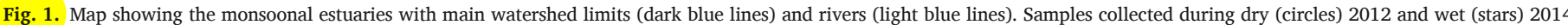

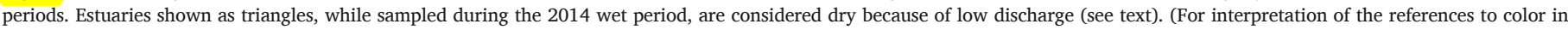
this figure legend, the reader is referred to the web version of this article.) 
discharge in the Indian estuaries.(Sarma et al., 2014). At the time of sampling, discharge was typically high during wet period in all estuaries except the southeastern estuaries (Ponnaiyar, Vellar, Vaigai and Cauvery) that have low discharge all year long because of limited rainfall during the southwest monsoon and high water use upstream. Moreover, SW monsoon was particularly late in 2014 and at the time of sampling, Krishna (SE) estuary was still at low discharge. The "wet" period sampling of these five estuaries will therefore be treated as dry period, since discharge was indeed low. During actual dry period sampling, discharge was very low in all the estuaries (Table 1 ).

\subsection{Measurement of amorphous (ASi) and lithogenic silica (LSi)}

There is a growing interest in understanding the Si biogeochemical cycle and analysis of ASi has become essential in aquatic and soil biogeosciences. The correct measurement of ASi in the suspended matter is required in order to recognize the fate and forms of Si along the land-to-ocean continuum. The diversity of silicate minerals can bias ASi estimates, making its measurement challenging, especially in estuaries and rivers. Among the several existing protocols, the most widely used methods for ASi determination in suspended matter are wet chemical alkaline digestions using $\mathrm{Na}_{2} \mathrm{CO}_{3}$ (Conley, 1998) or $\mathrm{NaOH}$ (Ragueneau et al., 2005). However, the resulting ASi concentrations can sometimes differ by an order of magnitude, depending on the protocol. Indeed, these chemical leaching protocols do not allow to differentiate biogenic silica (BSi) from ASi; hence when we use the term ASi to represent the $\mathrm{Si}$ extracted by digestion process, it includes BSi. We use the method described by Ragueneau et al. (2005) because it was developed especially for suspended matter with high silicate mineral contents.

For ASi measurement, chemical leaching is performed on a known fraction of the filter used to measure TSM. The filter aliquots were subjected to a wet alkaline digestion process, in which the released aluminium allows to correct the lithogenic contribution (Ragueneau et al., 2005). This method relies on three assumptions, 1) All aluminium measured is derived from silicate minerals, 2) All the biogenic silica is dissolved during first digestion, so the second leach should be representative of the Si:Al ratio of silicate minerals only and 3) Silicate minerals removed during second digestion have the same $\mathrm{Si}: \mathrm{Al}$ ratio as those dissolved during the first digestion. Uncertainty on ASi measurement is estimated to be $\sim 10 \%$. All silicon concentrations were measured by spectrophotometer. We obtain a mean measured Si concentration of $112.8 \pm$ $2.68 \mu \mathrm{M}, \mathrm{n}=82$ (97.4\% reproducibility) for the certified reference material (PERADE-09, supplied by environment Canada, lot no: 0314, with $\mathrm{Si}=109.96 \pm 6.97 \mu \mathrm{M})$.

The ASi measured is below detection limit or yielding negative values in the case of 41 (out of 143) samples of the dry period and 14 (out of 48) samples of the wet period. This is caused by the high lithogenic contribution during the first step, leading to an overestimation of the correction. It does not necessarily mean that the ASi concentration is low, since the detection limit depends more on the LSi contamination during the first leaching (with this contamination being correlated to the total LSi concentration) than the ASi content itself.

\subsection{Statistical analysis}

Significant seasonal differences for all the studied parameters are identified using Excel-T-test assuming unequal variance and are reported with a significance level of p-value $<0.05$. Standard deviations around mean value are given as $\pm 1 \sigma_{\mathrm{D}}$ in all tables. Similarly, the significance level for correlations is calculated using degrees of freedom (number of data) at $95 \%$ confidence level. Coefficients of determination $\left(\mathrm{R}^{2}\right)$ of linear regressions are given only for such significant relationships.
We use the ordination analysis (Principal Component Analysis PCA, and clustering on PCA results) for the discussion of biogeochemical processes. However, negative and missing data are not allowed in this processing. Therefore, the ASi negative values were calculated using the best linear relationship between ASi and fucoxanthin for the dry period and between ASi and TSM for the wet period (see Section 3). These values, recalculated for negative ASi values, are only used for PCA and clustering interpretations (Sections 3.2, 4.3 and 4.4) but not for the comparison of concentrations with literature, $\mathrm{Si}: \mathrm{N}$ ratios and flux calculations (Sections 4.1, 4.2 and 4.5).

For statistical interpretation (PCA and clustering), we separate all the estuaries into two main categories. We consider separately upper (salinity $<5$ ) and lower (salinity $>5$ ) estuaries categories for the following reasons: (i) the low salinity can be representative of the freshwater end-member, i.e. what is supplied to the estuary from rivers with little influence of seawater on concentrations (seawater contribution being max. $11 \%$ ) or processes like flocculation, turbidity, marine phytoplankton seeding, etc. (ii) the second category (salinity $>5$ ) should indeed be the most representative of processes specific to estuarine systems since it has a large salinity gradient. This category should more particularly highlight the processes controlled by seawater intrusion which can have a significant influence, e.g. on estuarine turbidity maximum for salinity only slightly above 5 (Schoelhamer, 2001; Sarma et al., 2012; Suja et al., 2016; Shynu et al., 2015). Moreover, the higher salinity of the samples from this category can also allow better estimation of the actual supply to the coastal ocean.

In addition, the estuaries holding more than one sample point under the same salinity category were averaged, to avoid repetition of the estuary in different clusters of the same category. Finally, before applying the ordination method, all the data is normalised and standardised (scaling and centering) in order to avoid the differences in data dimensions. Salinity, DSi, ASi, LSi, fucoxanthin, TSM, DIN and POC are used to identify the main biogeochemical processes (e.g., biological or non-biological) that govern the ASi, LSi and DSi contents. In a second statistical processing, land use and other main watershed characteristics features are compared to the same ASi, LSi and DSi contents to assess their impact on the Si cycle.

Hierarchical clustering on PCA results is performed in order to group the estuaries based on their similar behaviour and to deliver evidence regarding the dominant variable(s) in each cluster. The PCA and clustering on PCA results are performed using the R statistical program (https://www.r-project.org/) version 0.98 .1103 (using FactoMineR package). In our study, PCA combined with cluster analysis, provided a synthetic classification of estuaries in response to the respective characterizing variables. Generally, we consider only such PC axes for which the Eigen values are greater than 1 while explaining the variability of biogeochemical parameters.

For each cluster, the ratio between the mean of the cluster and the overall mean of the category estuary (hereafter ratio (mean) $_{\text {) }}$ ) is calculated. This ratio gives the most influent or characteristic variable(s) of the cluster. The ratio departing from 1 indicates either a strong enrichment (ratio $\gg 1$ ) or a strong depletion (ratio $\ll 1$ ) of that particular variable characterising the cluster. Note that all dominant variables are determined at the significance level of $\mathrm{p}<0.05$. Hence, thereinafter, whenever the $\mathrm{p}$-value is not given, is indicative of $\mathrm{p}<0.05$.

\section{Results}

Tables 2 and 3 provide the results of DSi, ASi, LSi, TSM, fucoxanthin, DIN and POC concentrations averaged $\left( \pm \sigma_{\mathrm{D}}\right)$ for each estuary during the dry and wet periods respectively, while individual data is provided as a graph in Appendix A. 
Table 2

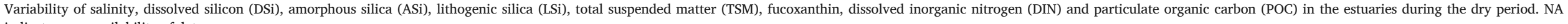
indicates non-availability of data.

\begin{tabular}{|c|c|c|c|c|c|c|c|c|c|c|c|c|c|c|c|c|c|c|}
\hline & & $\begin{array}{l}\text { Name of } \\
\text { river/Estuary }\end{array}$ & Salinity & & $\mathrm{DSi}$ & & $\mathrm{ASi}$ & & LSi & & TSM & & Fucox & & DIN & & POC & \\
\hline & & & Avg & $\begin{array}{l}\text { SD } \\
( \pm)\end{array}$ & $\mu \mathrm{M}$ & $\begin{array}{l}\text { SD } \\
( \pm)\end{array}$ & $\mu \mathrm{M}$ & $\begin{array}{l}\text { SD } \\
( \pm)\end{array}$ & $\mu \mathrm{M}$ & $\begin{array}{l}\text { SD } \\
( \pm)\end{array}$ & $\mathrm{mg} / \mathrm{l}$ & $\begin{array}{l}\text { SD } \\
( \pm)\end{array}$ & $\mu \mathrm{g} / 1$ & $\begin{array}{l}\text { SD } \\
( \pm)\end{array}$ & $\mu \mathrm{M}$ & $\begin{array}{l}\text { SD } \\
( \pm)\end{array}$ & $\mu \mathrm{M}$ & $\begin{array}{l}\text { SD } \\
( \pm)\end{array}$ \\
\hline & & Dry period & & & & & & & & & & & & & & & & \\
\hline \multirow{14}{*}{$\begin{array}{l}\text { Rivers } \\
\text { Flowing } \\
\text { in to } \\
\text { Bay of } \\
\text { Bengal, } \\
\text { East } \\
\text { coast }\end{array}$} & $\begin{array}{l}\text { North } \\
\text { east }\end{array}$ & Haldia & 4.7 & 0.9 & 88 & 42 & NA & & 875 & 729 & 143 & 117 & 0.3 & 0.1 & 29 & 4 & 231 & 92 \\
\hline & & Subernereka & 4.3 & 0.5 & 159 & 12 & 7.0 & 7.6 & 189 & 109 & 30 & 7 & 1.5 & 0.5 & 9 & 2 & 104 & 20 \\
\hline & & Baitharani & 17.5 & 4.4 & 37 & 12 & 0.6 & 0.7 & 207 & 85 & 56 & 13 & 0.7 & 0.5 & 10 & 3 & 135 & 27 \\
\hline & & Rushikulya & 20.4 & 2.8 & 63 & 28 & 1.4 & 0.4 & 54 & 12 & 27 & 2 & 0.4 & 0.1 & 7 & 2 & 57 & 17 \\
\hline & & Vamsadhara & 11.6 & 11.7 & 189 & 165 & 2.2 & 1.6 & 48 & 24 & 22 & 8 & 0.5 & 0.2 & 4 & 1 & 59 & 8 \\
\hline & & Nagavalli & 6.4 & 10.2 & 306 & 163 & 3.7 & 0.6 & 30 & 11 & 8 & 4 & 2.1 & 0.5 & 12 & 3 & 64 & 29 \\
\hline & & Mahanadi & 7.3 & 4.0 & 100 & 48 & 0.8 & 0.3 & 53 & 30 & 16 & 7 & 0.3 & 0.2 & 6 & 2 & 60 & 20 \\
\hline & $\begin{array}{l}\text { South } \\
\text { east }\end{array}$ & Krishna & 15.8 & 8.3 & 113 & 97 & 5.0 & 4.7 & 50 & 42 & 52 & 34 & 1.2 & 1.4 & 20 & 21 & 54 & 9 \\
\hline & & Cauvery & 7.9 & 7.6 & 285 & 89 & 8.8 & 3.6 & 60 & 42 & 23 & 9 & 5.2 & 4.1 & 6 & 5 & 127 & 22 \\
\hline & & Penna & 9.8 & 9.8 & 140 & 73 & 3.5 & 4.0 & 36 & 32 & 14 & 11 & 1.9 & 1.3 & 13 & 6 & 63 & 0 \\
\hline & & Ponnaiyar & 5.2 & 9.2 & 389 & 187 & 17.4 & 18.9 & 105 & 121 & 77 & 25 & 8.6 & 7.1 & 9 & 4 & 106 & 12 \\
\hline & & Vellar & 10.1 & 10.6 & 298 & 179 & 6.9 & 3.1 & 105 & 57 & 53 & 37 & 2.9 & 2.4 & 13 & 11 & 203 & 61 \\
\hline & & Vaigai & 11.6 & 8.6 & 154 & 59 & NA & & 133 & 59 & 67 & 13 & 0.3 & 0.3 & 10 & 3 & 124 & 0 \\
\hline & & Ambullar & 4.2 & 0.0 & 317 & 5 & 2.5 & 0.7 & 40 & 5 & 17 & 14 & 0.2 & 0.1 & 7 & 1 & 95 & 23 \\
\hline \multirow{13}{*}{$\begin{array}{l}\text { Rivers } \\
\text { Flowing } \\
\text { in } \\
\text { Arabian } \\
\text { sea, } \\
\text { west } \\
\text { coast }\end{array}$} & $\begin{array}{l}\text { South } \\
\text { west }\end{array}$ & Kochi BW & 8.4 & 9.4 & 79 & 33 & 2.1 & 1.8 & 43 & 28 & 76 & 29 & 1.8 & 2.0 & 13 & 7 & 50 & 12 \\
\hline & & Bharathapuzha & 10.8 & 12.6 & 74 & 32 & 4.9 & 3.1 & 78 & 37 & 32 & 18 & 1.1 & 1.2 & 5 & 6 & 98 & 40 \\
\hline & & Chalakudy & 14.7 & 11.9 & 57 & 13 & 1.1 & 0.7 & 15 & 7 & 17 & 16 & 0.5 & 0.4 & 7 & 3 & 50 & 6 \\
\hline & & Netravathi & 8.0 & 12.0 & 90 & 32 & 3.4 & 1.4 & 115 & 118 & 29 & 25 & 2.7 & 1.9 & 5 & 2 & 74 & 26 \\
\hline & & Kali & 1.6 & 1.5 & 89 & 32 & 1.1 & 0.8 & 26 & 12 & 63 & 4 & 0.4 & 0.5 & 20 & 15 & 55 & 3 \\
\hline & & Zuari & 20.7 & 13.2 & 42 & 17 & 1.9 & 3.2 & 30 & 13 & 51 & 17 & 1.6 & 1.2 & 10 & 2 & 66 & 6 \\
\hline & & Mandovi & 20.9 & 8.5 & 38 & 20 & 1.8 & 2.1 & 29 & 15 & 42 & 19 & 2.4 & 3.2 & 12 & 5 & 45 & 8 \\
\hline & North & Tapti & 9.0 & 15.3 & 136 & 76 & $\mathrm{NA}$ & & 1393 & 1306 & 418 & 448 & 1.2 & 1.4 & 29 & 14 & NA & \\
\hline & & Narmada & 3.8 & 7.3 & 164 & 50 & NA & & 171 & 124 & 22 & 16 & 0.7 & 0.5 & 37 & 6 & NA & \\
\hline & & Mahisagar & 0.2 & 0.0 & 278 & 4 & 0.7 & 0.3 & 42 & 21 & 28 & 22 & 0.8 & 0.9 & 82 & 1 & NA & \\
\hline & & Sabarmathi & 13.5 & 19.0 & 127 & 54 & NA & & 1482 & 214 & 209 & 177 & 5.2 & 0.0 & 49 & 14 & NA & \\
\hline & & $\begin{array}{l}\text { Dry upper } \\
\text { overall mean }\end{array}$ & 1.7 & 1.4 & 219 & 132 & 3.5 & 3.2 & 220 & 386 & 57 & 68 & 1.8 & 1.9 & 20 & 21 & 138 & 196 \\
\hline & & $\begin{array}{l}\text { Dry estuary } \\
\text { overall mean }\end{array}$ & 18.1 & 5.2 & 96 & 51 & 4.6 & 6.2 & 288 & 655 & 54 & 69 & 2.2 & 2.8 & 15 & 16 & 93 & 56 \\
\hline
\end{tabular}


Table 3

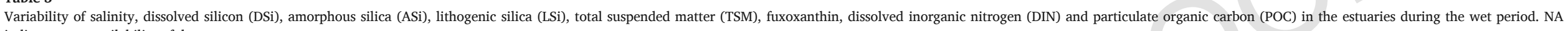
indicates non-availability of data.

\begin{tabular}{|c|c|c|c|c|c|c|c|c|c|c|c|c|c|c|c|c|c|}
\hline & \multirow[t]{2}{*}{ Name of Estuary } & \multicolumn{2}{|c|}{ Salinity } & \multicolumn{2}{|l|}{$\mathrm{DSi}$} & \multicolumn{2}{|l|}{$\mathrm{ASi}$} & \multicolumn{2}{|l|}{ LSi } & \multicolumn{2}{|l|}{ TSM } & \multicolumn{2}{|c|}{ Fucoxanthin } & \multicolumn{2}{|l|}{ DIN } & \multicolumn{2}{|c|}{ POC } \\
\hline & & Avg & $\begin{array}{l}\text { SD } \\
( \pm)\end{array}$ & $\mu \mathrm{M}$ & $\begin{array}{l}\text { SD } \\
( \pm)\end{array}$ & $\mu \mathrm{M}$ & $\begin{array}{l}\text { SD } \\
( \pm)\end{array}$ & $\mu \mathrm{M}$ & $\begin{array}{l}\text { SD } \\
( \pm)\end{array}$ & $\mathrm{mg} / 1$ & $\begin{array}{l}\text { SD } \\
( \pm)\end{array}$ & $\mu \mathrm{g} / 1$ & $\begin{array}{l}\text { SD } \\
( \pm)\end{array}$ & $\mu \mathrm{M}$ & $\begin{array}{l}\text { SD } \\
( \pm)\end{array}$ & $\mu \mathrm{M}$ & $\begin{array}{l}\text { SD } \\
( \pm)\end{array}$ \\
\hline & Wet period & & & & & & & & & & & & & & & & \\
\hline \multirow{4}{*}{$\begin{array}{l}\text { North } \\
\text { east }\end{array}$} & Haldia (ganges) & 3.6 & 2.0 & 113 & 9 & 9.8 & 7.1 & 2076 & 367 & 566 & 272 & 0.5 & 0.1 & 29.0 & 18.9 & 131 & 35 \\
\hline & Subernereka & 6.2 & 5.5 & 150 & 43 & 12.6 & 11.5 & 443 & 196 & 67 & 29 & 0.7 & 0.4 & 18.5 & 12.3 & 41 & 14 \\
\hline & Rushikulya & 10.6 & 9.2 & 170 & 77 & 19.1 & 29.6 & 604 & 932 & 90 & 125 & 0.4 & 0.5 & 19.3 & 11.5 & 35 & 37 \\
\hline & Mahanadi & 2.6 & 4.3 & 134 & 30 & NA & & 1227 & 471 & 185 & 59 & - & - & 28.7 & 31.2 & 68 & 8 \\
\hline \multirow{5}{*}{$\begin{array}{l}\text { South } \\
\text { east }\end{array}$} & Godavari & 0.6 & 0.6 & 147 & 13 & 22.3 & 16.8 & 1338 & 193 & 200 & 32 & & & 54.1 & 16.9 & 76 & 9 \\
\hline & krishna & Cons & as Dry & becaus & Jo run & no rain & aring sa & C & & & & & & & & & \\
\hline & Cauvery & & & & & & & & & & & & & & & & \\
\hline & Penna & & & & & & & & & & & & & & & & \\
\hline & $\begin{array}{l}\text { Ponnaiyar } \\
\text { Vellar }\end{array}$ & & & & & & & & & & & & & & & & \\
\hline \multirow{5}{*}{$\begin{array}{l}\text { South } \\
\text { west }\end{array}$} & Kochi BW & 4.6 & 7.0 & 101 & 16 & NA & & 294 & 204 & 50 & 30 & 0.7 & 0.6 & 38.0 & 25.7 & 100 & 27 \\
\hline & Netravathi & 0.1 & 0.0 & 130 & 19 & NA & & 164 & 48 & 30 & 7 & 0.5 & 0.0 & 23.8 & 16.6 & 29 & 4 \\
\hline & Kali & 4.9 & 3.8 & 112 & 8 & 0.5 & 0.6 & 62 & 28 & 15 & 7 & 0.2 & 0.1 & 6.3 & 1.1 & 21 & 5 \\
\hline & Zuari & 4.2 & 4.4 & 101 & 11 & NA & & 233 & 189 & 41 & 30 & 0.5 & 0.1 & 15.9 & 9.9 & 37 & 15 \\
\hline & Mandovi & 3.1 & 4.9 & 115 & 16 & 0.8 & 1.1 & 90 & 31 & 20 & 7 & 0.2 & 0.2 & 15.6 & 17.2 & 24 & 9 \\
\hline \multirow{5}{*}{$\begin{array}{l}\text { North } \\
\text { west }\end{array}$} & Tapti & 12.8 & 10.2 & 219 & 154 & 44.2 & 35.1 & 2925 & 3366 & 2104 & 2109 & 2.0 & 0.4 & 44.2 & 18.2 & 37 & - \\
\hline & Narmada & 15.6 & 12.1 & 188 & 105 & 22.7 & 22.5 & 1041 & 592 & 334 & 355 & 0.4 & 0.1 & 37.7 & 17.6 & 39 & 17 \\
\hline & Mahisagar & 6.8 & 7.9 & 285 & 115 & 12.5 & 18.6 & 754 & 880 & 151 & 192 & 0.5 & 0.5 & 39.0 & 12.4 & 33 & 21 \\
\hline & $\begin{array}{l}\text { Wet upper overall } \\
\text { mean }\end{array}$ & 1.1 & 1.0 & 193 & 109 & 12.4 & 19.1 & 691 & 780 & 125 & 172 & 0.5 & 0.4 & 27.0 & 14.0 & 56 & 36 \\
\hline & $\begin{array}{l}\text { Wet estuary overall } \\
\text { mean }\end{array}$ & 12.3 & 4.2 & 119 & 28 & 16.7 & 19.7 & 944 & 1156 & 197 & 212 & 0.8 & 0.6 & 22.0 & 19.0 & 39 & 23 \\
\hline
\end{tabular}




\subsection{Seasonal variability}

\subsubsection{Dissolved silicon (DSi)}

The average DSi concentration of Indian upper estuaries (salinity < 5 , considered representative of the freshwater river end-member) is 213 $\pm 139 \mu \mathrm{M}$ during the dry period and $163 \pm 88 \mu \mathrm{M}$ during the wet period. During the dry period, the concentration of DSi is associated with greater variability compared to the wet period. During the dry period, there is a significantly higher DSi concentration in the eastern estuaries $(179 \pm 142 \mu \mathrm{M})$ compared to the western $(88 \pm 63 \mu \mathrm{M})$ estuaries $(\mathrm{p}<$ $0.001)$. In contrast, there is no such significant difference between east $(143 \pm 43 \mu \mathrm{M})$ and west $(151 \pm 90 \mu \mathrm{M})$ during the wet period $(\mathrm{p}=0.7)$.

\subsection{2. $A S i$}

The ASi concentration ranges between 0.07 and $80 \mu \mathrm{M}$ (Appendix A for individual samples, Tables 2 and 3 for average values). Unlike DSi, ASi is significantly variable between seasons ( $p<0.001)$ at large spatial scale, with lower average ASi during the dry period $(4.2 \pm 6.3 \mu \mathrm{M})$ than during the wet period $(15.3 \pm 20.2 \mu \mathrm{M})$. During the dry period, the eastern estuaries show significantly higher ASi $(5.6 \pm 7.8 \mu \mathrm{M})$ compared to the western estuaries $(2.2 \pm 2.3 \mu \mathrm{M})(\mathrm{p}<0.001)$. No such significant difference is observed between east $(16.4 \pm 17.6 \mu \mathrm{M})$ and west $(14 \pm$ $22 \mu \mathrm{M})$ flowing estuaries during the wet period.

Phytoliths were not counted to assess their contribution to the ASi pool; however some particle samples collected in Krishna (SE) and Rushikulya (NE) estuaries (where there was a large salinity gradient during dry and wet periods), were examined under SEM (Scanning Electron Microscope) analysis in order to look at the composition of biogenic material. This confirmed a predominant presence of healthy diatom cells during the dry period and fragmented diatom cells along with clay mineral components during the wet period (not shown).

\subsubsection{Fucoxanthin}

Fucoxanthin is a diatom marker pigment, and its average concentrations in Indian estuaries are $1.86 \pm 2.81$ and $0.56 \pm 0.5 \mu \mathrm{g} / 1$ during the dry and wet periods respectively (Tables 2 and 3). During the dry period, there is a significant positive relation between ASi and fucoxanthin $\left(\mathrm{R}^{2}=0.40 \mathrm{n}=102\right.$, excluding 2 high ASi outliers, Fig. 2) indicating that diatoms play a major role in ASi contents. However, only $40 \%$ of the ASi variability can be explained by the fucoxanthin, i.e. diatoms. No such positive relationship is noticed during wet season.



Fig. 2. Best linear fit of ASi vs. fucoxanthin, to calculate the missing ASi. Two outliers (red triangles) from the small estuary Ponnaiyar (SE estuary) are excluded from the regression due to their very high ASi concentrations. Note that the regression line equation is used to recalculate the missing and negative ASi concentrations of the dry season for the PCA (see text). (For interpretation of the references to color in this figure legend, the reader is referred to the web version of this article.)

\subsubsection{LSi (Lithogenic silicon) and total suspended material (TSM)}

The average concentrations of LSi are $143 \pm 343 \mu \mathrm{M}$ and $720 \pm$ $743 \mu \mathrm{M}$ during dry and wet periods respectively. LSi is found to be particularly high in some estuaries, especially in the northern estuaries Haldia (NE), Tapti and Sabarmathi (NW) even during the dry period (Table 2 and Appendix A). Other than that, LSi is higher during the wet period than during dry period in all the estuaries (Table 3). Unlike ASi and DSi which vary significantly between seasons and location (east or west coast), no such difference is shown on LSi ( $p=0.27$ and 0.16 for the dry and wet periods respectively).

TSM is highly variable within each estuary across the salinity gradient (Tables 2 and 3) as well as for the dry (53 $\pm 87 \mathrm{mg} / \mathrm{l})$ and wet (302 $\pm 774 \mathrm{mg} / \mathrm{l}$ ) periods. $95 \%$ and $60 \%$ of all samples have less than or equal to $100 \mathrm{mg} / \mathrm{l}$ of TSM during the dry and wet periods respectively. In most of the estuaries, in the dry period ( $80 \%$ of the samples), TSM is of moderate concentration (50-60 mg/l) with significant contribution of chl-a (not shown) and fucoxanthin, suggesting that turbidity may not act as a hurdle for the diatoms to grow as already discussed in Sarma et al. (2012). In contrast, a positive relationship is observed between TSM and discharge in Indian estuaries during the wet period $\left(\mathrm{R}^{2}=0.78, \mathrm{n}\right.$ $=11$, excluding 2 estuaries), which confirms earlier findings in the Indian estuaries (Sarma et al., 2014). Haldia and Tapti estuaries are excluded from this relation because of their very low discharge and high TSM concentration (for Tapti) and vice versa (for Haldia). This is counterintuitive and may be due to the use of recalculated discharge data (10 years' average contribution, as described above) instead of the actual data at the time of sampling.

During the wet period, there is a significant positive relationship between TSM vs. ASi $\left(\mathrm{R}^{2}=0.45, \mathrm{n}=34\right)$ and TSM vs. LSi $\left(\mathrm{R}^{2}=0.86\right.$, $\mathrm{n}=49$ ) indicating the control of particulate Si supply via discharge. However, this TSM vs. ASi relationship is stronger when split into upper $\left(\mathrm{R}^{2}=0.70\right)$ and lower $\left(\mathrm{R}^{2}=0.68\right)$ estuaries respectively (Fig. 3$)$. In addition, there is a significant positive relation between TSM and total particulate $\mathrm{Si}$ ( $\mathrm{ASi}+\mathrm{LSi}, \mathrm{R}^{2}=0.71$, not shown) indicating that total particulate $\mathrm{Si}$ is mainly influenced by TSM. During the dry season, there is no significant relationship between ASi and TSM. However, a significant positive relationship exists between TSM vs. total particulate $\mathrm{Si}$ (ASi + LSi; $\left.R^{2}=40, n=146\right)$ and TSM vs. LSi $\left(R^{2}=0.60, n=146\right.$, excluding two outliers) indicating that the particulate Si pool is mainly controlled by lithogenic contribution in the estuaries during the dry period but this is mostly due to the latter (LSi).

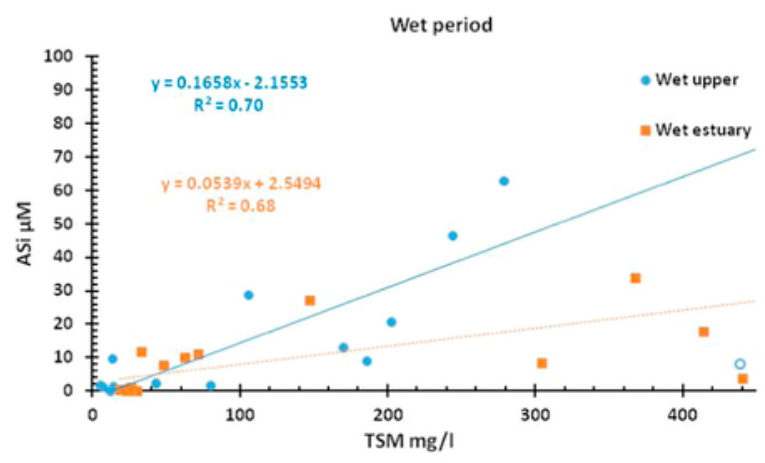

Fig. 3. Best linear fit between ASi and TSM for wet season (circles: upper wet; squares: lower wet). TSM value of estuary Haldia (NE, station 1, blue open circle) is excluded from the regression of the wet period upper estuaries. Similarly, for lower estuaries, the best fit between ASi and TSM (closed boxes). Data for the estuary Tapti (NW, station 3) was excluded from the regression because its TSM concentration exceeds average by more than one order of magnitude ( $3572 \mathrm{mg} / \mathrm{l})$ and is not shown in the graph. Note that the regression line equations are used to recalculate the missing and negative ASi concentrations of the wet season for the PCA (see text). (For interpretation of the references to color in this figure legend, the reader is referred to the web version of this article.) 


\subsubsection{DIN and POC}

The average DIN distribution of Indian estuaries varies between 14.1 $\pm 15.2 \mu \mathrm{M}$ and $28.5 \pm 20.1 \mu \mathrm{M}$ during the dry and wet periods respectively (Tables 2 and 3) with significant seasonal differences. Similarly, the average POC of Indian estuaries varies between $94.4 \pm 93.7 \mu \mathrm{M}$ and $51.8 \pm 37 \mu \mathrm{M}$ during the dry and wet periods respectively, again with significant seasonal differences. A significant positive relation between TSM vs. POC $\left(\mathrm{R}^{2}=0.43, \mathrm{n}=42\right)$ and TSM vs. DIN $\left(\mathrm{R}^{2}=0.13, \mathrm{n}=\right.$ 50 ), indicating POC and DIN have a terrestrial supply origin and are related to lithogenic processes (more strongly by POC than DIN), will be treated below, when detailing the PCA results.

\subsection{Inter-estuary variability}

In order to investigate the pattern of variability of the biogeochemical parameters among the different estuaries, we apply, as explained in Section 2.4, PCA to the seasonal data, followed by clustering of PCA results in the two salinity categories $<5$ and $>5$ salinity Results are shown in Table 4. In the upper estuarine region, three PCs are identified explaining a total variance of $78 \%$ in the dry season and two PCs that explain $70 \%$ of total variance in the wet season. In the lower estuarine region, the numbers of axes for dry and wet seasons are 3 and 2 PCs, respectively, explaining $77-78 \%$ of the variability.

\subsubsection{Dry period}

3.2.1.1. Upper estuaries From the results shown in Table 4, PC1 is strongly related to the parameters ASi, POC, TSM and LSi, in increasing order. Therefore, estuaries falling on the positive side of PC1 are dominated by lithogenic processes such as weathering and erosion as a first order (primary) control (Fig. B1). In contrast, PC2 is primarily influenced by biogenic parameters (ASi, fucoxanthin) and the estuaries falling under this axis might be controlled by diatom production as a second order control. The influence of salinity and DIN is well pronounced in the third axis (explaining $20 \%$ of variability), therefore representing only a third order control. Based on the PCA results, clusters of estuaries from different geographic locations are identified (Fig. 4A). The dominant variables of each cluster are described in Table 5A. The complete dataset for all categories used for this ordination technique are provided as tables in Appendix B.

The estuaries of cluster 1 belong to eastern and northwestern regions and are dominated by high DIN ( ratio $_{(\text {mean }}$ greater than $>1$ ) and lower TSM and salinity ( ratio $_{\text {(mean) }}<1$ ). Cluster 2 mainly consists of estuaries from eastern and southwestern locations which are characterized by higher salinity and relatively less DSi and DIN concentrations compared to the mean upper dry (Table 5A). Cluster 3 mainly consists of southeast and Sabarmathi (NW) estuaries characterized by high fucoxanthin, ASi and DSi, showing no association with lithogenic variable. Cluster 4 consists of northern estuaries (Haldia and Tapti) and is highly controlled by lithogenic parameters with POC, LSi and TSM with ratio $_{\text {(mean) }} \gg 1$ (Table 5A).

3.2.1.2. Lower estuaries $\mathrm{PC} 1$ and PC2, with strong associations of POC, TSM and LSi (34\%) and fucoxanthin, ASi and DIN (27\%), can clearly be considered as the signature of non-biogenic and biogenic processes respectively. PC3 (17\%) with strong association for salinity represents the mixing of seawater (Table 4). The combined PCA and cluster analysis for lower estuaries allows for the distinction of three clusters (Fig. 4B).

The estuaries of cluster 1 (10 out of 21 estuaries) are from all regions except northwest, and are characterized by low ASi, LSi, POC and DSi (Table 5B). Estuaries from cluster 2 are all from eastern regions. Cluster 3 comprises the eastern and northwestern estuaries. This cluster is mainly characterized by higher LSi, TSM and DIN concentrations (Table $5 B)$.

\subsubsection{Wet period}

3.2.2.1. Upper estuary The overall variability and the significant correlation of the biogeochemical parameters to the PC axis are depicted in the Table 4 and Fig. B5. In total, 70\% of the variability is explained by the first two axes (PC1 and PC2). The strong positive relations of DIN, ASi, POC, TSM and LSi parameters with axis 1 clearly shows that monsoonal discharge supplies a huge quantity of TSM along with weathered products (secondary and primary minerals) as well as organic plant materials. PC2 exhibits strong positive correlation with DSi and fucoxanthin and negative correlation with salinity (Table 4). Based on the PCA results, clusters of estuaries from different geographic locations in the case of upper estuary are identified (Fig. 4C). The dominant variables of each cluster are described in Table 5C. The complete dataset for all categories used for the ordination technique are provided as tables in Appendix B.

In cluster 1, DIN is the unique characteristic variable with $80 \%$ lower concentration than the overall mean of the category. The upper Khali estuary was sampled for the wet season from the shore around a mangrove area, which might explain these data particulars.

Cluster 3 (only Tapti in NW) is mainly characterized by higher DSi and fucoxanthin (Table 5C). Together with high ASi $(9.8 \mu \mathrm{M})$, even though not different from the category mean, this indicates the possible signature for diatom occurrence. This suggests a relatively minor lithogenic impact compared to that in other clusters.

Interestingly, there is no significant characteristic variable governing the estuaries of cluster 2 (three estuaries from western regions) and cluster 4 (four estuaries from northeast and western regions). This means that none of the variables are significantly different from the overall mean and that they can thus be considered as representative of the average upper wet estuaries. The estuaries of these two clusters are relatively close to one another on the factor map (Fig. 4C). Cluster 6 also represents a single estuary (Haldia, NE), but this estuary is quite remote from the location of the estuaries of clusters 2 and 4. Notably,

Table 4

Correlation coefficient (r) between PC axes and variables for the dry and wet periods. The values in bold are significant at $\mathrm{p}<0.05$ level.

\begin{tabular}{|c|c|c|c|c|c|c|c|c|c|c|}
\hline \multirow[t]{2}{*}{ Variables } & \multicolumn{3}{|c|}{ Upper -dry $(n=22)$, sal $<5$} & \multicolumn{3}{|c|}{ Lower -dry $(n=21)$, sal $>5$} & \multicolumn{2}{|c|}{$\begin{array}{l}\text { Upper -wet }(n=13) \text {, sal } \\
<5\end{array}$} & \multicolumn{2}{|c|}{$\begin{array}{l}\text { Lower -wet }(n=11) \text {, sal } \\
>5\end{array}$} \\
\hline & $\begin{array}{l}\text { PC 1 } \\
(33 \%)\end{array}$ & $\begin{array}{l}\text { PC } 2 \\
(25 \%)\end{array}$ & $\begin{array}{l}\text { PC 3 } \\
(20 \%)\end{array}$ & $\begin{array}{l}\text { PC } 1 \\
(34 \%)\end{array}$ & $\begin{array}{l}\text { PC } 2 \\
(27 \%)\end{array}$ & $\begin{array}{l}\text { PC } 3 \\
(17 \%)\end{array}$ & $\begin{array}{l}\text { PC } 1 \\
(50 \%)\end{array}$ & $\begin{array}{l}\text { PC } 2 \\
(20 \%)\end{array}$ & $\begin{array}{l}\text { PC } 1 \\
(58 \%)\end{array}$ & $\begin{array}{l}\text { PC } 2 \\
(19 \%)\end{array}$ \\
\hline Salinity & 0.05 & -0.42 & 0.73 & 0.22 & -0.28 & 0.82 & -0.10 & -0.62 & 0.62 & 0.01 \\
\hline DSi & -0.22 & 0.73 & -0.03 & 0.62 & 0.37 & -0.48 & -0.09 & 0.82 & 0.64 & -0.76 \\
\hline TSM & 0.88 & -0.30 & -0.03 & 0.66 & -0.46 & 0.24 & 0.94 & -0.20 & 0.91 & -0.01 \\
\hline POC & 0.83 & -0.02 & -0.16 & 0.65 & 0.25 & -0.31 & 0.93 & -0.08 & 0.35 & 0.86 \\
\hline DIN & 0.05 & 0.01 & -0.89 & 0.58 & -0.60 & -0.13 & 0.81 & 0.16 & 0.89 & -0.13 \\
\hline $\mathrm{ASi}$ & 0.47 & 0.70 & 0.48 & 0.47 & 0.82 & 0.2 & 0.83 & 0.29 & 0.92 & 0.00 \\
\hline $\mathrm{LSi}$ & 0.90 & -0.05 & -0.07 & 0.78 & -0.44 & -0.09 & 0.95 & -0.15 & 0.93 & 0.00 \\
\hline Fuco & 0.22 & 0.85 & 0 & 0.45 & 0.64 & 0.49 & 0.06 & 0.62 & 0.62 & 0.47 \\
\hline
\end{tabular}



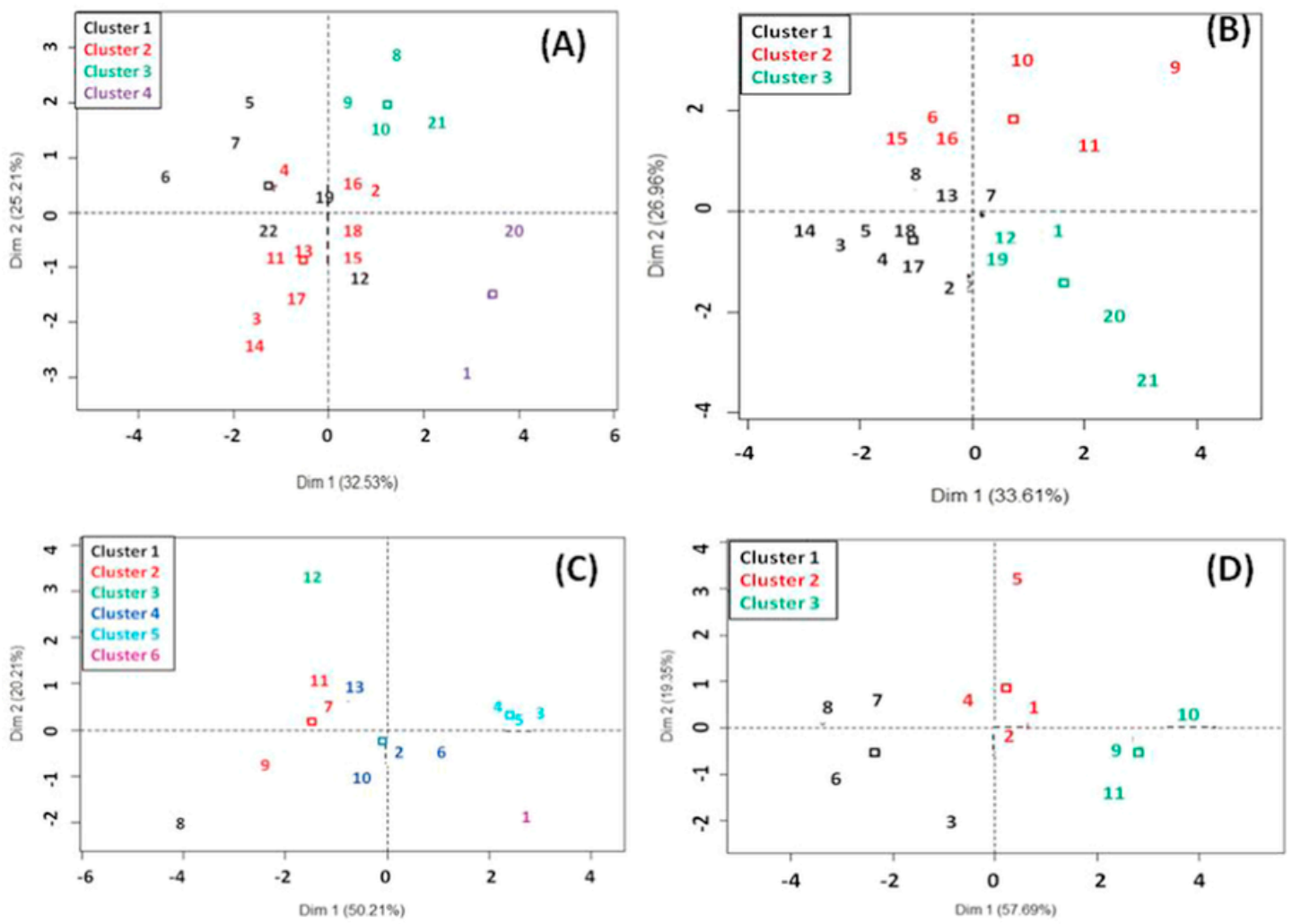

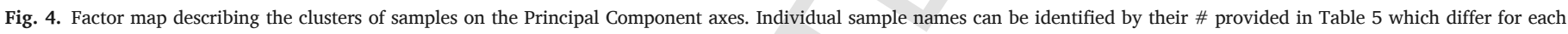
panel. A: Upper estuaries, dry period. B: Lower estuaries, dry period. C: Upper estuaries, wet period. D: Lower estuaries, wet period.

Haldia is linked to the Ganges-Brahmaputra system, which is known to behave differently from the other Indian rivers due to its more perennial supply of freshwater. Finally, cluster 5 includes only estuaries from the eastern region. These estuaries are characterized by high TSM, LSi and ASi (Table 5C).

3.2.2.2. Lower estuary In total, $77 \%$ of variability is explained by PC1 and PC2 (Table 4 and Fig. B6). PC1 alone explains 58\% of variability with strong relationships with salinity, LSi, TSM, DIN, ASi, and fucoxanthin towards the positive end of the axis (Table 4). The remaining $19 \%$ is explained by PC2 with strong relationship of DSi towards negative and POC towards positive end of the PC2 axis. The suspended material via river runoff is naturally considered to be the dominant controlling mechanism for LSi, ASi, and TSM source to the estuaries in high discharge season, though there is significant influence of salinity, i.e. mixing with seawater.

The clustering of PCA results (Fig. 4D and Table 5D) reveals clustering of estuaries from northeast and southwest regions (cluster 1), estuaries from the same regions but not included in cluster 1 (cluster 2) and the three estuaries from NW (cluster 3). Cluster 2 is similar to some upper estuary clusters and has no characteristic biogeochemical variable.

\section{Discussion}

\subsection{Biogeochemistry of the Si pools}

\subsubsection{Comparison with previous Si data in rivers}

The ASi values observed in the Indian estuaries are within the range of world estuaries and comparable with other tropical estuaries (Table 6). Weathering and erosion via terrigenous supply played a dominant role on the particulate $\mathrm{Si}$ pool, including $\mathrm{ASi}$, during the wet period. A similar observation was made for the river Huanghe, China, where high erosion of topsoils is responsible for higher ASi supply (Ran et al.,
2015). Higher DSi content in the eastern estuaries, compared to the western estuaries, may be explained by different soil-water interaction times during which silicon leached, as observed for other tropical rivers such as Tana in Kenya (Dunne, 1978; Hughes et al., 2012). The east coast Indian estuaries belong to larger watersheds, with wider plains and longer residence times of soil-water interaction, compared to the west coast estuaries with smaller watershed and steeper slopes (Nayak and Hanamgond, 2010).

Before reaching the coastal water, the DSi concentrations in estuaries are altered through several mechanisms - dilution with seawater, biological uptake, sediment settling, dissolution or adsorption - desorption (Struyf et al., 2005; Zhu et al., 2009; Lehtimäki et al., 2013; Lu. et al., 2013; Carbonnel et al., 2013; Raimonet et al., 2013). In the present study, the observed DSi concentration of the upper estuaries are similar to those reported earlier for Indian rivers (Sarma et al., 2009; Gurumurthy et al., 2012; Meunier et al., 2015; Frings et al., 2015) and other tropical rivers (Liu et al., 2009; Hughes et al., 2011, 2012, 2013; Ran et al., 2015). The abundance of diatoms in the Si pool is consistent with the share of diatoms in the total phytoplankton counts of $61 \pm 26 \%$ among the estuaries during dry period (Durga Bharathi, 2014).

The calculated contribution of ASi to the mobile Si pool (ASi / (ASi + DSi)) shows higher ASi contribution during wet season $(8.8 \pm 10 \%)$ compared to dry season $(3.5 \pm 5 \%)$. The results are lower than those of the other world river systems (16\%; Conley, 1997) and Huanghe River (65\% during high flow; Ran et al., 2015) but comparable to the tropical systems such as river Congo (6\%; Hughes et al., 2011) and slightly higher than those observed for the Amazon basin (3\%; Hughes et al., 2013).

The variability of LSi in Indian estuaries is comparable to that of the Aulne estuary (56-573 $\mu \mathrm{M})$ in France (Ragueneau et al., 2005) and the tropical Changjiang estuary $(560 \pm 1410 \mu \mathrm{M})$ in China (Lu et al., 2013). It is in accordance with previous studies in the Godavari estuary 
Table 5

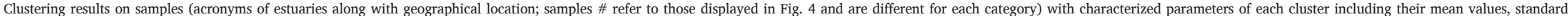

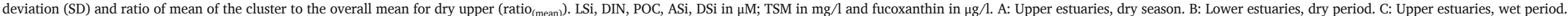
D: Lower estuaries, wet period.

\begin{tabular}{|c|c|c|c|c|c|c|c|c|c|c|c|c|c|c|}
\hline & \multicolumn{7}{|c|}{ 5A- Upper estuaries - dry period } & \multicolumn{7}{|c|}{ 5B- Lower estuaries - dry period } \\
\hline & Estuaries & $\begin{array}{l}\text { Characterized } \\
\text { variable }\end{array}$ & $\begin{array}{l}\text { Cluster } \\
\text { mean }\end{array}$ & SD & $\begin{array}{l}\text { Overall } \\
\text { mean }\end{array}$ & SD & Ratio $_{\text {(mean) }}$ & Estuaries & $\begin{array}{l}\text { Characterized } \\
\text { variable }\end{array}$ & $\begin{array}{l}\text { Cluster } \\
\text { mean }\end{array}$ & SD & $\begin{array}{l}\text { Overall } \\
\text { mean }\end{array}$ & SD & Ratio $_{\text {(mean) }}$ \\
\hline \multirow[t]{3}{*}{$\begin{array}{l}\text { Cluster } \\
1\end{array}$} & $\begin{array}{l}\text { NE: Nag } \\
\text { (5), SE: } \\
\text { Pen (7), } \\
\text { Kris (6), } \\
\text { Vai (12); } \\
\text { NW: Nar } \\
\text { (19), Mahi } \\
\text { (22). }\end{array}$ & DIN & 38 & 33 & 20 & 21 & 1.9 & $\begin{array}{l}\text { NE: Bai } \\
\text { (2) Maha } \\
\text { (3), Rus } \\
\text { (4), Vam } \\
\text { (5); SE: } \\
\text { Pen (8), } \\
\text { Kris (7); } \\
\text { SW: KBW } \\
\text { (13), Cha } \\
\text { (14), Zua } \\
\text { (17), Man } \\
\text { (18). }\end{array}$ & $\mathrm{ASi}$ & 2.1 & 1.2 & 4.2 & 5.5 & 0.5 \\
\hline & & TSM & 25 & 31 & 57 & 68 & 0.4 & & $\mathrm{LSi}$ & 57 & 55 & 288 & 655 & 0.2 \\
\hline & & Sal & 0.4 & 0.2 & 1.7 & 1.4 & 0.2 & & $\begin{array}{l}\text { DSi } \\
\text { POC }\end{array}$ & $\begin{array}{l}63 \\
60\end{array}$ & $\begin{array}{l}24 \\
28\end{array}$ & $\begin{array}{l}96 \\
93\end{array}$ & $\begin{array}{l}51 \\
56\end{array}$ & $\begin{array}{l}0.7 \\
0.6\end{array}$ \\
\hline \multirow[t]{4}{*}{$\begin{array}{l}\text { Cluster } \\
2\end{array}$} & $\begin{array}{l}\text { NE: Sub } \\
\text { (2),Maha } \\
\text { (3), Vam } \\
\text { (4); SE: } \\
\text { Amb (11); } \\
\text { SW: KBW } \\
\text { (13), Cha } \\
\text { (14), Bha } \\
\text { (15),Net } \\
\text { (16), Kali } \\
\text { (17), Zua } \\
\text { (18). }\end{array}$ & Sal & 2.5 & 1.2 & 1.7 & 1.4 & 1.5 & $\begin{array}{l}\text { NE: Nag } \\
\text { (6); SE: } \\
\text { Pon (9), } \\
\text { Cau (10), } \\
\text { Vel (11); } \\
\text { SW: Bha } \\
\text { (15), Net } \\
\text { (16). }\end{array}$ & ASi & 9.8 & 8.1 & 4.2 & 5.5 & 2.3 \\
\hline & & $\mathrm{DSi}$ & 152 & 107 & 219 & 132 & 0.7 & & Fuco & 4.5 & 4.1 & 2.2 & 2.8 & 2.1 \\
\hline & & DIN & 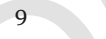 & 6 & 20 & 21 & 0.5 & & POC & 127 & 57 & 93 & 56 & 1.4 \\
\hline & & & & & & & & & DIN & 6.7 & 4.2 & 15.3 & 16 & 0.4 \\
\hline \multirow[t]{3}{*}{$\begin{array}{l}\text { Cluster } \\
3\end{array}$} & $\begin{array}{l}\text { SE: Pon } \\
\text { (8), Cau } \\
\text { (9), Vel } \\
\text { (10); NW: } \\
\text { Sab (21). }\end{array}$ & Fuco & 5.03 & 1.56 & 1.76 & 1.87 & 2.9 & $\begin{array}{l}\text { NE: Hal } \\
\text { (1); SE : } \\
\text { Vai (12); } \\
\text { NW : Nar } \\
\text { (19), Tap } \\
\text { (20), Sab } \\
\text { (21). }\end{array}$ & DIN & 38 & 19 & 15 & 16 & 2.5 \\
\hline & & $\mathrm{ASi}$ & 8.07 & 3.48 & 3.54 & 2.92 & 2.3 & & $\mathrm{LSi}$ & 1168 & 1190 & 288 & 655 & 4.1 \\
\hline & & $\mathrm{DSi}$ & 358 & 141 & 219 & 132 & 1.6 & & TSM & 123 & 141 & 54 & 69 & 2.3 \\
\hline \multirow[t]{3}{*}{$\begin{array}{l}\text { Cluster } \\
4\end{array}$} & $\begin{array}{l}\text { NE : Hal } \\
(1) \text { and } \\
\text { NW: Tap } \\
(20)\end{array}$ & POC & 587 & 465 & 138 & 196 & 4.3 & No cluster & & & & & & \\
\hline & & LSi & 1026 & 359 & 220 & 386 & 4.7 & & & & & & & \\
\hline & 5C- Upper & $\begin{array}{l}\text { TSM } \\
\text { ies - Wet period }\end{array}$ & 247 & 58 & 57 & 68 & 4.3 & 5D - Lowe & aries - Wet perio & & & & & \\
\hline $\begin{array}{l}\text { Cluster } \\
1\end{array}$ & $\begin{array}{l}\text { SW: Kali } \\
(8)\end{array}$ & & & & & & & $\begin{array}{l}\text { NE: Rus } \\
\text { (3); SW: } \\
\text { Kali } \\
\text { (6),Man } \\
\text { (7), Zua } \\
\text { (8). }\end{array}$ & DIN & 7.5 & 5.3 & 22 & 19 & 0.3 \\
\hline
\end{tabular}


Table 5 (Continued)

\begin{tabular}{|c|c|c|c|c|c|c|c|c|c|c|c|c|c|c|}
\hline & \multicolumn{7}{|c|}{ 5A- Upper estuaries - dry period } & \multicolumn{7}{|c|}{ 5B- Lower estuaries - dry period } \\
\hline & Estuaries & $\begin{array}{l}\text { Characterized } \\
\text { variable }\end{array}$ & $\begin{array}{l}\text { Cluster } \\
\text { mean }\end{array}$ & SD & $\begin{array}{l}\text { Overall } \\
\text { mean }\end{array}$ & SD & Ratio $_{\text {(mean) }}$ & Estuaries & $\begin{array}{l}\text { Characterized } \\
\text { variable }\end{array}$ & $\begin{array}{l}\text { Cluster } \\
\text { mean }\end{array}$ & SD & $\begin{array}{l}\text { Overall } \\
\text { mean }\end{array}$ & SD & Ratio $_{\text {(mean) }}$ \\
\hline & & DIN & 5.4 & 0 & 27 & 14 & 0.2 & & TSM & 25 & 4 & 197 & 212 & 0.1 \\
\hline & & & & & & & & & $\mathrm{LSi}$ & 109 & 28 & 944 & 1156 & 0.1 \\
\hline & & & & & & & & & $\mathrm{ASi}$ & 1.3 & 2.2 & 16.1 & 19 & 0.1 \\
\hline Cluster & SW: Net & NULL & & & & & & NE: Hal & NULL & & & & & \\
\hline 2 & (7), Man & & & & & & & (1), Sub & & & & & & \\
\hline & Nar (11). & & & & & & & & & & & & & \\
\hline \multirow{5}{*}{$\begin{array}{l}\text { Cluster } \\
3\end{array}$} & NW: Tap & & & & & & & NW: Nar & TSM & 465 & 118 & 197 & 212 & 2.4 \\
\hline & $(12)$ & & & & & & & (9),Tap & & & & & & \\
\hline & & 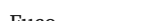 & 17 & 0 & 05 & 04 & 37 & & DC: & 15 & 0 & 110 & 0 & 70 \\
\hline & & $\mathrm{DSi}$ & 443 & 0 & 193 & $\begin{array}{l}0.4 \\
109\end{array}$ & $\begin{array}{l}3.7 \\
2.3\end{array}$ & & DIN & $\begin{array}{l}102 \\
50\end{array}$ & 5 & 22 & $\begin{array}{l}28 \\
19\end{array}$ & $\begin{array}{l}1.3 \\
2.3\end{array}$ \\
\hline & & & & & & & & & $\mathrm{LSi}$ & 2305 & 1382 & 944 & 1156 & 2.4 \\
\hline Cluster & NE: Sub & NULL & & & & & & No cluster & & & & & & \\
\hline 4 & (2); SW: & & & & & & & & & & & & & \\
\hline & KBW (6), & & & & & & & & & & & & & \\
\hline & Zua (10); & & & & & & & & & & & & & \\
\hline & $\begin{array}{l}\text { NW: Mahi } \\
\text { (13) }\end{array}$ & & & & & & & & & & & & & \\
\hline \multirow{6}{*}{$\begin{array}{l}\text { Cluster } \\
\mathbf{5}\end{array}$} & $\begin{array}{l}\text { (13) } \\
\text { NE: Rus }\end{array}$ & $\mathrm{ASi}$ & 39 & 21 & 13 & 18 & 30 & & & & & & & \\
\hline & (3), Maha & & & & & & & & & & & & & \\
\hline & (4); SE: & & & & & & & & & & & & & \\
\hline & God (5). & & & & & & & & & & & & & \\
\hline & & LSi & 1594 & 357 & 691 & 780 & 2.3 & & & & & & & \\
\hline & & TSM & 229 & 43 & 125 & 172 & 1.8 & & & & & & & \\
\hline $\begin{array}{l}\text { Cluster } \\
6\end{array}$ & $\begin{array}{l}\text { NE : Hal } \\
\text { (1) }\end{array}$ & NULL & & & & & & & & & & & & \\
\hline
\end{tabular}


Table 6

ASi or BSi distribution in world rivers/estuaries, including the present study upper estuaries.

\begin{tabular}{|c|c|c|}
\hline River/estuary & $\begin{array}{l}\text { ASi } \mu \mathrm{mol} / 1 \\
\text {-range }\end{array}$ & Ref. \\
\hline \multicolumn{3}{|l|}{ Tropical } \\
\hline Huanghe river & $15.7-285$ & Xiangbin et al. (2015) \\
\hline Nyong basin river & $0.40-1.16$ & Cary et al. (2005) \\
\hline Congo river & $0.9-40.8$ & Hughes et al. (2011) \\
\hline Amazon river & $<$ DL-13.4 & Hughes et al. (2013) \\
\hline Changjiang river & $0.5-4.0$ & Cao et al. (2013) \\
\hline $\begin{array}{l}\text { Lake malawi (Shire River } \\
\text { outflow) }\end{array}$ & $2.9-69.9$ & Bootsma et al. (2003) \\
\hline Ganges & $<$ DL to 300 & Frings et al. (2014) \\
\hline Youngjiang & 1.7 & Liu et al. (2005) \\
\hline $\begin{array}{l}\text { Indian estuaries-upstream- } \\
\text { dry }\end{array}$ & $0.16-36.45$ & present study \\
\hline $\begin{array}{l}\text { Indian estuaries - upstream } \\
\text { wet }\end{array}$ & $0.19-62.78$ & present study \\
\hline \multicolumn{3}{|l|}{ Subtropical } \\
\hline Estuary of Taiwan & $4.98-6.05$ & Wu and Chou (2003) \\
\hline \multicolumn{3}{|l|}{ Temperate } \\
\hline Scheldt estuary & $7.0-81.0$ & Carbonnel et al. (2013) \\
\hline Baltic sea catchments & $0-100$ & Humborg et al. (2006) \\
\hline Oder river & $10.4-100.2$ & Sun et al. (2013) \\
\hline Mississippi river USA & 14.1 & Conley (1997) \\
\hline Daugava river & $1.0-12.0$ & Aigars et al. (2014) \\
\hline Rhine river & $1.4-5.93$ & Admiraal et al. (1990) \\
\hline Vantaa river estuary & $11-192$ & Lehtimäki et al. (2013) \\
\hline \multicolumn{3}{|l|}{ Polar } \\
\hline Lena river & $4.0-17.0$ & $\begin{array}{l}\text { Heiskanen and Keck } \\
\text { (1996) }\end{array}$ \\
\hline
\end{tabular}

(Sarma et al., 2009, 2014). The results from the Haldia estuary (566 \pm $272 \mathrm{mg} / \mathrm{l}$ ) and other Indian estuaries are found to be in the range of Ganges and comparable with other European estuaries, despite largely varying TSM concentrations in the former $(49-2000 \mathrm{mg} / \mathrm{l}$ at surface; Frings et al., 2014) and in the latter (a few mg/l to few g/l; Middelburg and Herman, 2007).

\subsubsection{Comparison with previous ASi data in Indian rivers}

The only previous study on ASi in the Ganges river of the Indian subcontinent showed ASi is highly variable (from below detection limit to $>300 \mu \mathrm{M}$ ) and its origin cannot be explained by biogenic causes only (Frings et al., 2014). Our results confirm these findings. Compared to that of the Ganges basin, the ASi and TSM variabilities in other major and minor estuaries observed in this study, are lower. The concentrations of suspended matter $(50 \mathrm{mg} / \mathrm{l}$ to several $\mathrm{g} / \mathrm{l}$ ) and ASi (ranging from below detection limit to up to $300 \mu \mathrm{M}$ ) in Ganges are often several times higher compared to our data from other Indian estuaries (e.g. average for wet upper estuaries: $11 \pm 15 \mu \mathrm{M}$ for ASi and $123 \pm$ $200 \mathrm{mg} / \mathrm{l}$ for TSM, cf. Table 1). Comparing both studies is not trivial, for several reasons. (i) The Frings et al. (2014) study dealt with a single one of India's largest river basins, Ganges, whereas the present study surveys several estuaries with a wide range of sizes. (ii) Unlike other rivers in India (monsoonal rivers), the Ganges basin is a perennial river with relatively low seasonal variability on its discharge and is characterized by particularly high TSM due to high erosion of the Himalayan mountains. (iii) There might be a methodological issue on ASi measurement as Frings et al. (2014) used a $1 \% \mathrm{Na}_{2} \mathrm{CO}_{3}$ leaching (Clymans et al., 2011) while the current study uses $0.2 \mathrm{M} \mathrm{NaOH}$ (Ragueneau et al., 2005). This $\mathrm{Na}_{2} \mathrm{CO}_{3}$ method was found to potentially overestimate ASi, whereas the use of the strong $\mathrm{NaOH}$ base may underestimate ASi (Barão et al., 2015). Although the ASi values of the present study are several times lower than the mean ASi $(68 \mu \mathrm{M})$ of Ganges, the relationship between TSM and ASi of our data set follows the same logarithmic trend as Frings et al. (2014) for surface waters (Fig. 5). Indeed, our upper wet estuaries TSM versus ASi variability is consistent with the trend

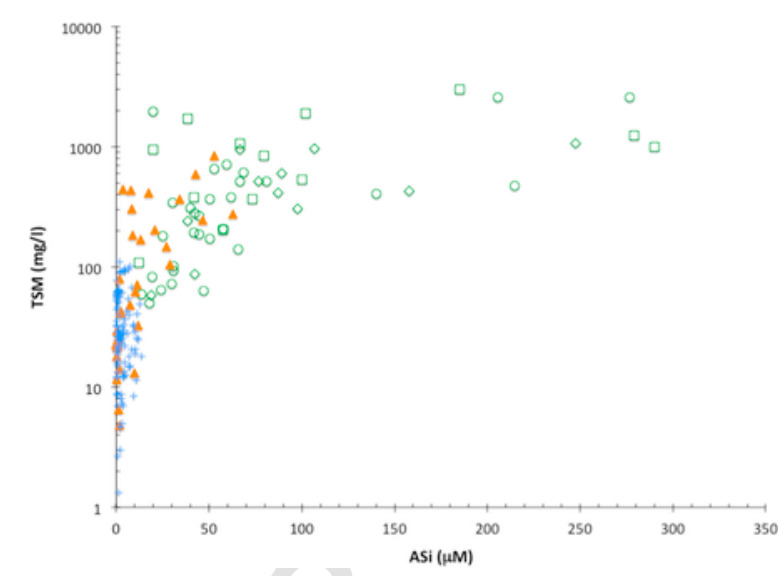

Fig. 5. Comparison of TSM vs. ASi in Ganges river (green circles: surface; green diamonds: mid-depths; green squares: deep samples; data from Frings et al., 2014) and Indian estuaries (orange triangles: wet season; blue crosses: dry season; this study). (For interpretation of the references to color in this figure legend, the reader is referred to the web version of this article.)

of Frings et al. (2014) as our average TSM is $125 \mathrm{mg} / \mathrm{l}$ (Table 2). According to the Ganges TSM - ASi relationship, this should correspond to $12-40 \mu \mathrm{M}$ ASi (Fig. 5) and we find $12 \mu \mathrm{M}$ (Table 2). Hence, we can be confident there is no methodology issue in our ASi estimates since the orders of magnitude in both studies are consistent and the relatively lower TSM we find in our Indian estuaries can explain our lower ASi compared to those from Ganges, (Fig. 5).

\subsection{Si:N ratios and coastal eutrophication potential}

In all estuaries, the DSi:DIN ratios are much higher than the "Redfield-Brzezinski ratio" needed for diatoms which is $\sim 1$ under non-limiting conditions (Brzezinski, 1985): for the upper estuaries, the average Si:N ratios are 9.8 (range of 1.4-25, excluding one outlier at $>400$ ) and 23 (range of 2.3-155) during wet and dry seasons, respectively. The average Si:N ratios of the highest salinity samples is 12 (range of 1.5-85) for both wet and dry seasons. Hence, whatever the season, either in the freshwater end-member (i.e. supply to estuaries) or higher saline samples (i.e. supply to the coastal North Indian Ocean), Si is never limiting relative to N. Consequently, the Indicators for Coastal Eutrophication Potential (ICEP) which "represent the new production of non-siliceous algal biomass potentially sustained in the receiving coastal water body by either nitrogen (...) delivered in excess over silica" (Garnier et al., 2010) will all be negative, meaning that coastal eutrophication should not take place around the mouth of our studied estuaries. Whether this explains why coastal Indian waters rarely face eutrophication and/or whether such absence of eutrophication is due to strong coastal currents inducing quick dilution and/or high turbidity (Rao and Sarma, 2013; Krishna et al., 2016) remains to be confirmed, but clearly, high silicon supply to the coast, even downstream the estuarine filter, is likely to play a significant role. Sarma et al. (2013) observe Si:N ratios mostly above 1 along the coastal Bay of Bengal and attribute them to high supply of Si from rivers. Noteworthy, we do not observe seasonal variation of DSi:DIN ratios of the estuarine supply to the coast.

\subsection{Inter-estuary biogeochemical processes}

Apart from seasonal variability in biogeochemical processes, the distinct functioning of each estuary is also determined by non-seasonal features such as geographical location (climate), topography (e.g., larger watershed size and smoother slopes in the east) and land-use practices (e.g., type of agriculture, urbanization etc.). All these proper- 
ties affect runoff and biogeochemical characteristics making it hard to isolate the processes controlling the variability occurring in estuaries by looking at the whole dataset using only regional averages as discussed above. Principal Component Analysis allows for better inter-comparison of the samples and will identify the parameters explaining variability in concentrations of ASi, LSi and DSi, independently of the region of sampling (e.g. Xue et al., 2011).

\subsubsection{Dry period}

4.3.1.1. Upper estuary Cluster 1, characterized by high DIN, suggests more supply of nitrogen via artificial fertilizer usage, which is especially true for the northern estuaries. The anthropogenic activities such as supply of domestic waste, agriculture and industrial activity are likely responsible for the higher, dominating DIN in these estuaries $(150 \mathrm{~kg} /$ ha fertilizer usage in Gujarat-NW region compared to other western states like Kerala, $113 \mathrm{~kg} / \mathrm{h}$, and Maharashtra $134 \mathrm{~kg} / \mathrm{h}$ Ministry of agriculture, 2012-2013). This confirms the higher impact of fertilizer usage in the northern estuaries reported by Sarma et al. (2014), using nitrogen isotopes.

Cluster 2 mainly consists of estuaries from northeastern and southwestern locations characterized by higher salinity and relatively lower DSi and DIN concentrations compared to the mean upper dry (Table 5). This suggests that the seawater intrusion and low fresh water supply could be responsible for low DSi and DIN. Higher tidal amplitude in northern and smaller watersheds of southern estuaries favours more seawater characteristics and influences the biogeochemistry.

In the estuaries of cluster 3, high fucoxanthin and ASi indicate diatoms presence, while high DSi suggests the $\mathrm{Si}$ is coming from the dissolution/decomposition of biogenic material (e.g., dead diatoms or phytoliths) that have recently settled in the surface sediments. It is known that ASi dissolution at the sediment - water interface can be a significant supply of DSi in estuaries (Struyf et al., 2005; Delvaux et al., 2013; Raimonet et al., 2013). Our data do not allow quantifying such benthic flux, but we suggest that it should contribute significantly to the high DSi concentration in this cluster. Enhanced phytoplankton biomass associated with lower TSM was attributed with high in-situ production observed in the Indian estuaries (e.g. Godavari by Sarma et al., 2009 and 2014). For cluster 4, with high lithogenic contents, erosion continuously supplies terrigenous material with high suspended material load to the upper estuaries.

Overall, in the dry upper category, we show that the estuarine biogeochemistry variability is strongly dominated by diatoms (cluster 3), lithogenic processes (cluster 4) and, partly dominated by seawater intrusion (cluster 2), and by a possible anthropogenic impact (cluster 1).

4.3.1.2. Lower estuaries A combination of both biogenic (diatom uptake) and non-biogenic (lithogenic supply) processes explain the variability of Si parameters in the lower estuaries (Fig. 4B and Appendix B3). Though salinity explained $17 \%$ variability in PC3 of this category, none of the clusters were significantly controlled by salinity. Therefore the materials supplied from the upper estuaries may still be controlling the variability of LSi, TSM and DIN in these lower estuaries.

The estuaries of cluster 1 seem to be controlled by lithogenic processes, while the estuaries of cluster 2 support diatom production (higher ASi, fucoxanthin and POC and lower DIN) and three of these estuaries are in cluster 3 of the upper estuaries category (especially the southeast estuaries). Thereby, higher diatom production is favoured throughout the length of these estuaries. The lower estuaries of cluster 3 are mainly controlled by terrestrial (non-biogenic) supply of materials. Excepting Vaigai, these estuaries are all from the north, characterized by higher tidal amplitude that could favour sediment resuspension (7-10 $\mathrm{m}$ compared to 1-2 $\mathrm{m}$ for most of the other; Sarma et al., 2014).

\subsubsection{Wet period}

4.3.2.1. Upper estuary The strong positive relations of the DIN, ASi, POC, TSM and LSi parameters on axis 1 clearly suggest that monsoonal discharge is responsible for the huge TSM supply along with weathered products (secondary and primary minerals) as well as organic plant materials. This high erosion is the main factor controlling the biogeochemical variables of the upper estuaries during the wet period. However, the lithogenic control of material supply is variable among the identified clusters, the variability depending on the climate, discharge and the time of sampling. Salinity (mixing) exerts a second-order control on DSi. The clustering of PCA results (Fig. 4C and Table 5C) distinguishes Khali (SW, cluster 1), Tapti (NW, 3) and Haldia (NE, 6) as single estuary clusters, distinct from the other estuaries.

The association in cluster 5 reveals that terrigenous material supply via monsoon discharge is the clear controlling mechanism of Si variability here. Further, the terrestrial supplies contain a high level of ASi not originating from live diatoms as this high ASi was not related to high fucoxanthin. The ASi pool may contain diatom debris (as observed on SEM samples from Rushikulya, not shown) along with phytoliths and lithogenic ASi. Indeed, there should be a common process relating $\mathrm{ASi}$, LSi and TSM in this cluster as these three variables are higher by a similar enrichment factor (2-3) compared to the mean, the most likely responsible process being soil erosion.

4.3.2.2. Lower estuary In cluster 1 , the concentration of ASi, TSM, DIN and LSi are particularly lower than the mean (by -70 to $-95 \%$, Table $5 \mathrm{D}$ ), and this indicates that most of the lithogenic supply from the upstream has settled and will not reach the coastal ocean. This was particularly obvious for Rushikulya which is characterized by very high TSM and LSi in the upper estuary during wet season as compared to the lower estuary. Estuaries in this cluster 1 are from relatively smaller watersheds with steeper slopes (for SW) and smaller plains (Table 1). This may explain higher settling once the high particle load enters the estuary.

The estuaries of cluster 3 are mainly controlled by lithogenic supply, as evidenced by the TSM and LSi concentrations which are $\sim 2.5$ folds higher than the overall mean of the category. The estuaries under this category are usually larger in size and the rivers run in wider plains with heavy runoff during monsoon period. The average TSM and LSi of cluster 3 is much higher than TSM and LSi measured in the same estuaries upstream, highlighting the non-conservativity of these parameters (Appendix A). Because of the larger size and longer length of these estuaries, it is possible that lithogenic supply from land surrounding the estuary is significant and contributes to an increase in the particle load. Moreover, for the NW estuaries (Tapti, Narmada), the watersheds are characterized by semi-arid climate and vegetation that should favour more erosion. Noteworthy, Narmada and Tapti are in cluster 3 (lower dry category), also characterized by high DIN, TSM and LSi. As already mentioned, the tidal amplitude of northern estuaries is the highest (Sarma et al., 2014) and sediment resuspension is likely to be higher. In any case, these estuaries are an important source of particles to the coastal ocean.

The cluster 2 estuaries have large ranges of LSi, TSM and ASi concentrations $(759 \pm 592 \mu \mathrm{M}, 168 \pm 168 \mathrm{mg} / \mathrm{l}$ and $11.8 \pm 3.9 \mu \mathrm{M}$ respectively) which are very similar to those of the upper mean wet estuaries and it seems likely that in this category particulate material supplied by freshwater source is efficiently transferred to the lower estuary with little modification.

Overall, the lower wet estuaries are mainly controlled by the lithogenic processes, which are however of variable origins and fate within this lithogenic material, namely (i) efficient sediment trapping within the lower estuary (cluster 1), (ii) efficient transfer to the coastal ocean (cluster 2) and (iii) local input of lithogenic particles in the case of large estuarine watersheds (cluster 3). 


\subsection{Impact of land use on the Si cycle}

India being an agricultural country with $\sim 1.3$ billion inhabitants, an attempt has been made to visualize the impact of land use (agriculture, forest cover, built-up lands, water bodies) and other general watershed characteristics on the Si cycle in the Indian estuaries since earlier studies did demonstrate anthropogenic impact on continental Si cycle (e.g. Humborg et al., 2006, Conley et al., 2008; Struyf et al., 2010). The PCA results are analysed to envisage relationships among the variables and the prevailing land-use pattern affecting the Indian estuaries. The impact of land use can be better evidenced by the terrestrial supply tightly associated with discharge during wet period. Therefore the impact of land use is studied only on the Si parameters (ASi, DSi and LSi) during wet period on the mean estuary (upper + lower). The land-use and watershed characteristics data were obtained from http://www.india-wris. nrsc.gov.in/. Note that the NRSC-WRIS website provides regional averages for some adjacent watersheds of the same land-use pattern (Table 1). Contrary to PCA on all biogeochemical parameters, in this case the PC analysis is performed based only on the three Si parameters (DSi, ASi and $\mathrm{LSi}$ ) and the watershed characteristics as supplementary variables to see how they correlated to the PC axes. In addition to land use, we include runoff, slope, discharge and length of the river (representative of watershed surface since both are highly correlated with $\mathrm{R}^{2}=0.8$ ).

The PCA results explain $79 \%$ of the overall Si variability along the first axis and 19\% variability along the second axis. PC2 shows less variability (Eigen value $<1$ ) and no significant correlation with the variables can be observed (Fig. 6a and Table 7). The three highest correlations on the positive side of PC1 are with ASi, LSi and \% agriculture ( $\mathrm{r}$ close to 0.9 ) and, to a slightly lesser extent, for the length of the river and DSi ( $r=0.76$ each). This is consistent with higher agricultural activity and the fact that larger watersheds have increased supply of ASi and LSi while higher forest cover reduces soil erosion. Noteworthy is the fact that the northern estuaries (NE and NW; clusters 3-6) tend towards the positive end of PC1, whereas the southern (SW, clusters 1 and 2) estuaries tend towards the negative side of PC1. This
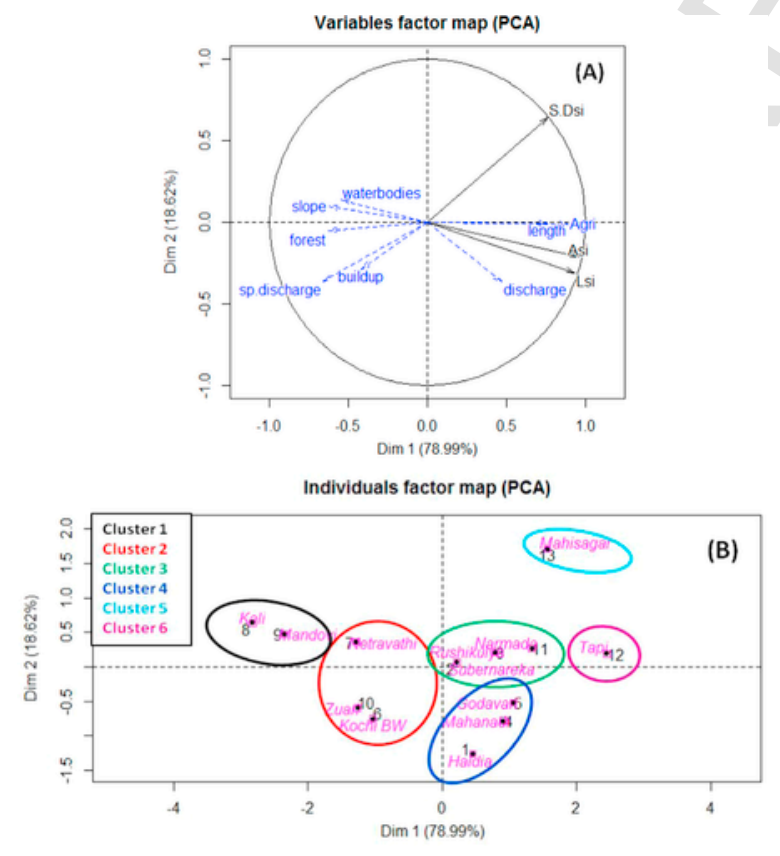

Fig. 6. a and b, PCA analysis on the impact of land use in the Indian estuaries during the wet period. ) Relationship among the variables and b) Individual factor map and clustering with Indian estuaries based on PCA results.
Table 7

Correlation of land use and Si variables on PC axis 1 and 2 during wet period.

\begin{tabular}{lll}
\hline Variables & \multicolumn{2}{l}{ Wet period (upper + lower) } \\
\hline & PC 1 (77.9\%) & PC 2 (17.8\%) \\
\hline ASi & $\mathbf{0 . 9 6}$ & -0.21 \\
LSi & $\mathbf{0 . 9 3}$ & -0.30 \\
DSi & $\mathbf{0 . 7 6}$ & 0.64 \\
Buildup & -0.42 & -0.28 \\
Agri & $\mathbf{0 . 8 9}$ & -0.01 \\
Forest & $-\mathbf{0 . 6 3}$ & -0.05 \\
Waterbodies & $-\mathbf{0 . 5 5}$ & 0.14 \\
length & $\mathbf{0 . 7 6}$ & 0 \\
Slope & $-\mathbf{0 . 6 2}$ & 0.09 \\
Discharge & 0.47 & -0.36 \\
Runoff & $-\mathbf{0 . 6 6}$ & -0.37 \\
\hline
\end{tabular}

could be explained by a relatively more extensive forest cover (avg. $35 \%$ ) in the SW region (Western Ghats) compared to other regions (avg. forest cover for the NE and NW regions, 26\%), preventing soil erosion. The SW rivers also have steeper slopes and less residence time of water especially when runoff is high, reducing the Si supply to the coastal water relative to the other eastern and northwestern estuaries. In contrast, the wider plains (longer watershed) and higher agriculture practice along the eastern and northwestern regions (avg 60\%) compared to SW region (avg 47\%) favours more supply of land-derived Si (via biogenic and lithogenic mechanisms) to the Bay of Bengal when compared to the Arabian Sea (Fig. 6b). Undoubtedly, increasing urbanization (e.g. deforestation) can also alter the Si cycle and changes in the Si supply to estuaries in the future, as shown in the case of estuaries elsewhere in the world (e.g. Humborg et al., 2006; Conley et al., 2008; Laruelle et al., 2009; Delvaux et al., 2013; Xiangbin et al., 2015).

\subsection{Fluxes of ASi, LSi and DSi to North Indian Ocean from Indian sub- continent}

Knowledge of riverine contributions of dissolved and particulate materials to the ocean is essential to understand the elemental fluxes and balances on a global scale. Taking the uncertainties on Si river fluxes to the ocean, especially in tropical environments (Tréguer and De La Rocha, 2013) into account, we calculate the total flux of DSi, ASi and LSi delivered by the upper estuaries to the North Indian Ocean. The Indian estuaries are mostly monsoonal estuaries and receive maximum runoff during the southwest monsoon period when most of the supply of materials via rivers also occurs (Subramanian et al., 2006). The wet season considered in this paper is the 4-month duration when $76 \pm 10 \%$ of annual discharge occurs in the estuaries (Table 1), and very high ASi and LSi concentrations are observed, compared to the dry season, even if DSi shows similar concentrations (Tables 2 and 3). Therefore, we calculate the material flux for the wet period as it should represent at least three-fourths of the annual Si flux. The flux is calculated by multiplying the wet season's discharge (Table 1) and the concentration of Si parameter of the upper estuaries and expressed as $\mathrm{Gmol}\left(10^{12} \mathrm{~mol}\right)$ for wet season. Uncertainties on these fluxes for each estuary are expressed in terms of (i) the standard deviation of wet season's discharge based on a 10 years average to take into account inter-annual variability of discharge, and (ii) the standard deviation of the mean upper wet ASi, DSi and LSi concentrations to take into account sampling variability. Where only one sample is available, we use the relative standard deviation of the closest estuary.

We estimate that the Indian monsoonal estuaries sampled in our study supply $49 \pm 6,3 \pm 1.6,303 \pm 47 \mathrm{Gmol}$ of DSi, ASi and LSi respectively to the upper estuaries of Northern Indian Ocean during wet season. Of these quantities, $55 \%$ of DSi, $92 \%$ of ASi and $94 \%$ of LSi are supplied to the Bay of Bengal and the rest to the Arabian Sea (Table 8). 
Table 8

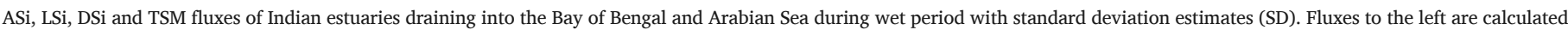

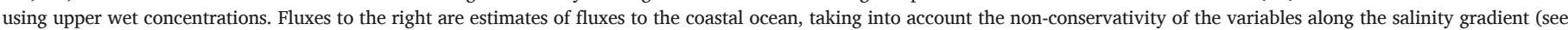

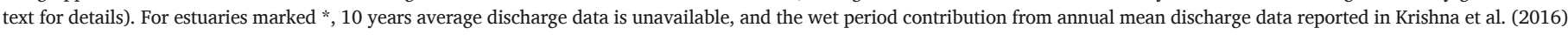

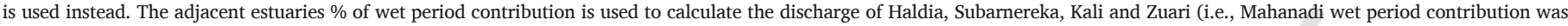
used for Haldia and Subarnareka; Netravathi was used for Kali and Mandovi for Zuari.).

\begin{tabular}{|c|c|c|c|c|c|c|c|c|c|c|c|c|}
\hline \multirow[b]{2}{*}{ Estuaries } & \multicolumn{6}{|c|}{ Bulk fluxes to upper estuaries } & \multicolumn{6}{|c|}{ Net fluxes to Ocean (assuming non-conservativity) } \\
\hline & DSi & $\mathrm{SD}$ & $\mathrm{ASi}$ & SD & $\mathrm{LSi}$ & SD & DSi & SD & ASi & SD & $\mathrm{LSi}$ & SD \\
\hline & \multicolumn{6}{|c|}{ Gmol/wet season } & \multicolumn{6}{|c|}{ Gmol/wet season } \\
\hline Haldia* & 4.3 & 0.4 & 0.22 & 0.11 & 85 & 7 & 5.7 & 0.5 & 0.5 & 0.27 & 77 & 6.8 \\
\hline Subarnarekha* & 1.7 & 0.3 & 0.15 & 0.17 & 5 & 3 & 1.3 & 0.2 & 0.1 & 0.10 & 4 & 2.3 \\
\hline Mahanadi & 7.5 & 1.7 & NA & & 72 & 24 & 6.0 & 1.4 & NA & & 64 & 21 \\
\hline Rushikulya & 0.2 & 0.1 & 0.06 & 0.02 & 2 & 0.6 & 0.1 & 0.1 & 0.0 & 0.01 & 0.3 & 0 \\
\hline Godavari & 13.3 & 4.0 & 2.02 & 1.62 & 121 & 39 & 12 & 3.5 & 0.6 & 0.47 & 94 & 30 \\
\hline Kochi BW & 0.8 & 0.1 & NA & & 2 & 2 & 1.0 & 0.1 & NA & & 13 & 11 \\
\hline Netravathi & 1.2 & 0.3 & 0.01 & 0.001 & 2 & 0.5 & 0.9 & 0.2 & NA & & 3 & 0.9 \\
\hline Kali* & 0.5 & 0.0 & 0.00 & 0.004 & 0.2 & 0.0 & 0.6 & 0.01 & 0.001 & 0.0007 & 0.4 & 0.1 \\
\hline Zuari* & 0.3 & 0.0 & NA & & 0.7 & 0.5 & 0.3 & 0.03 & NA & & 0.6 & 0.4 \\
\hline Mandovi & 0.3 & 0.1 & 0.00 & 0.001 & 0.2 & 0.1 & 0.3 & 0.1 & 0.0001 & 0.00004 & 0.6 & 0.2 \\
\hline Tapti & 4.3 & 0.2 & 0.09 & 0.004 & 0.6 & 0.0 & 2.7 & 0.1 & 0.6 & 0.03 & 48 & 2 \\
\hline Narmada & 11.2 & 3.0 & 0.09 & 0.02 & 10 & 3 & 14 & 3.7 & 1.1 & 0.30 & 217 & 59 \\
\hline Mahisagar & 3.4 & 2.0 & 0.02 & 0.01 & 3 & 3 & 2.5 & 1.5 & 0.2 & 0.11 & 189 & 249 \\
\hline $\begin{array}{l}\text { Bay of Bengal } \\
\text { (BOB) }\end{array}$ & 27 & 4.4 & 2.44 & 1.64 & 285 & 46 & 25 & 3.8 & 1.2 & 0.55 & 239 & 37 \\
\hline Arabian Sea (AS) & 22 & 3.6 & 0.22 & 0.03 & 18 & 5 & 22 & 4.0 & 1.9 & 0.32 & 472 & 256 \\
\hline $\begin{array}{l}\text { Total to north } \\
\text { Indian Ocean }\end{array}$ & 49 & 5.7 & 2.7 & 1.6 & 303 & 46 & 47 & 5.5 & 3.1 & 0.63 & 711 & 259 \\
\hline $\begin{array}{l}\text { Extrapolating to } \\
\text { total BoB }\end{array}$ & & & & & & & 211 & 32 & 10.3 & 4.7 & 2028 & 317 \\
\hline $\begin{array}{l}\text { Extrapolating to } \\
\text { total AS }\end{array}$ & & & & & & & 80 & 15 & 6.9 & 1.1 & 1717 & 932 \\
\hline
\end{tabular}

It is interesting to note that the supply of DSi to the Arabian Sea and the Bay of Bengal are comparable, while the ASi and LSi supply were 25 and 10 times higher for the Bay of Bengal.

From the above discussion, ASi, LSi, DSi and TSM do not necessarily follow a conservative behaviour along salinity gradient, even during the wet season (Appendix A). Therefore, we correct the fluxes during wet season to the upper estuaries for non-conservativity to obtain more relevant estimates for silicon fluxes to the coastal North Indian Ocean. Non-conservativity is estimated by recalculating the expected conservative concentration of the highest salinity sample available with respect to its measured concentration. We use coastal values (taken from literature) for the seawater end-member values and the lowest salinity station as fresh water end-member. Coastal seawater concentrations of DSi, ASi and LSi of $5 \mu \mathrm{M}, 2 \mu \mathrm{M}, 5 \mu \mathrm{M}$, respectively, are taken from Gupta et al. (1997), Naqvi et al. (2010) and Sarma et al. (2013). The non-conservative fluxes do not modify the DSi fluxes much, because most of the DSi variability adheres to conservative mixing during wet season. However, this is not the case for NW estuaries which show a dramatic increase of particle supply along the salinity gradient. These calculations show that the estuaries sampled east of the Arabian Sea (AS) and west of the Bay of Bengal supply fluxes of the same order of magnitude to their respective seas (Table 8).

Our results do not imply the total sediment supply to the Arabian Sea and the Bay of Bengal to be similar. It is well known that this is not the case, and the sediment supply to the entire Bay of Bengal is higher than the supply to the entire Arabian Sea (Nair et al., 1989; Ittekkot et al., 1991). The estuaries sampled in our study represent a discharge to the Arabian sea of $82 \pm 12 \mathrm{~km}^{3}$ which is $27 \%$ of the total discharge and $189 \mathrm{~km}^{3}$, representing hardly $12 \%$ of the total discharge to the Bay of Bengal (Table 8). Hence, our sampling coverage is higher in the Arabian Sea compared to Bay of Bengal during the wet period. Moreover, we did not sample Ganges-Brahmaputra, the largest river in the eastern coast draining into Bay of Bengal. In order to nullify the sampling effects we propose to extrapolate the non-conservative behaviour of the flux to the total discharge into Bay of Bengal $\left(1600 \mathrm{~km}^{3}\right)$ and Arabian
Sea $\left(300 \mathrm{~km}^{3}\right)$, taking into account the basin scale supply. Based on this extrapolation, we do indeed find a higher Si flux to the Bay of Bengal $(211 \pm 32,10 \pm 5,2028 \pm 317 \mathrm{Gmol})$ than to the Arabian Sea $(80 \pm 15$, $7 \pm 1,1717 \pm 932 \mathrm{Gmol}$ ) for DSi, ASi and LSi, respectively (Table 8). These Si fluxes calculated to the northern Indian Ocean (tropical side) might help to estimate the global coastal Si budget in the future.

\section{Conclusions}

1) Indian estuaries are highly diversified in terms of geographical situation (climate), topography, runoff and land-use practices. In this study, we have looked at the variability of amorphous, lithogenic and dissolved silicon as well as that of the main biogeochemical parameters relevant to $\mathrm{Si}$, in several Indian estuaries in wet and dry seasons. Overall, we show that $40 \%$ of the ASi variability in dry season is explained by diatoms while lithogenic supply explains most of the ASi variability during high discharge. However, the strengths of the processes responsible for the variability of LSi and ASi are not clearly evidenced when looking at the dataset as a whole nor when applying a categorisation based only on location (NE, NW, SE, SW). Therefore, we separated our data into two categories i) upper (salinity $<5$ ), and ii) lower estuaries (salinity $>5$ ) for dry and wet period respectively. We then performed PCA and clustering on PCA results on these categories for each season. We show that during dry period in the upper estuaries, diatom production is common, with possible dissolution in the eastern and some western estuaries. In addition, a strong lithogenic impact was observed in the northeast (especially Haldia) and the northwest (e.g. Tapti) estuaries. For the remaining estuaries, there was no clear process explaining Si variability of the entire estuary. By nature, different principal processes are observed in the upper and lower estuaries, due to different levels of seawater intrusion and anthropogenic activity over the extent of the estuary. 
2) In the wet season, a strong control of erosion is observed in all estuaries. The monsoon-driven discharge is likely the main control of particulate concentrations, especially in the lower estuaries.

3) Agricultural land use played a major role in the Si biogeochemical cycle, generally increasing fluxes in all forms - ASi, DSi and LSi.
The southwestern estuaries, however, seem to expose a different behaviour, as Si fluxes appear related to the region's greater forest cover which prevents soil erosion. The present work is the first study on particle Si variability in estuaries at the Indian subcontinent scale and confirms that the silicon cycle is impacted by anthro-
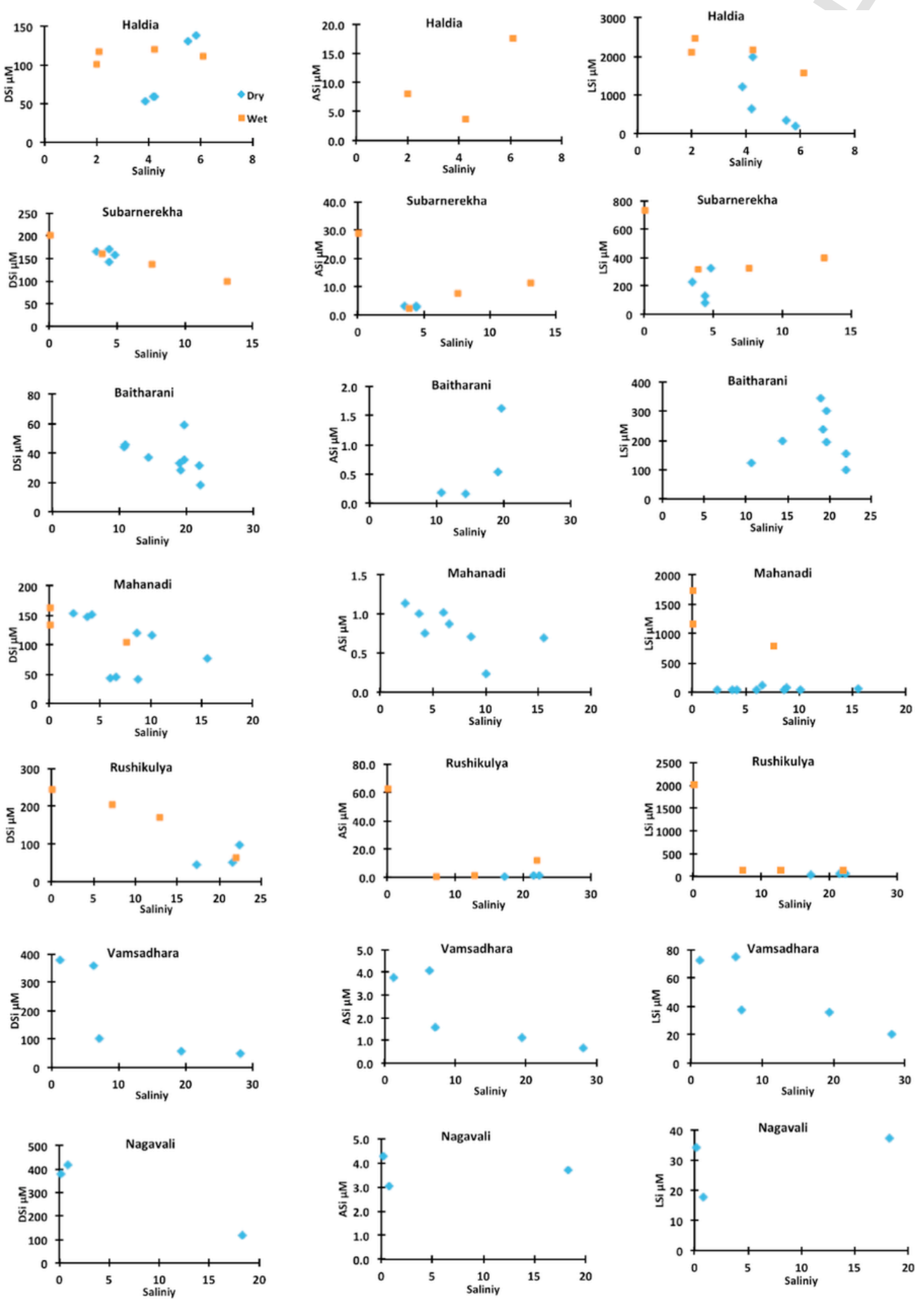


the reader is referred to the web version of this article.) 

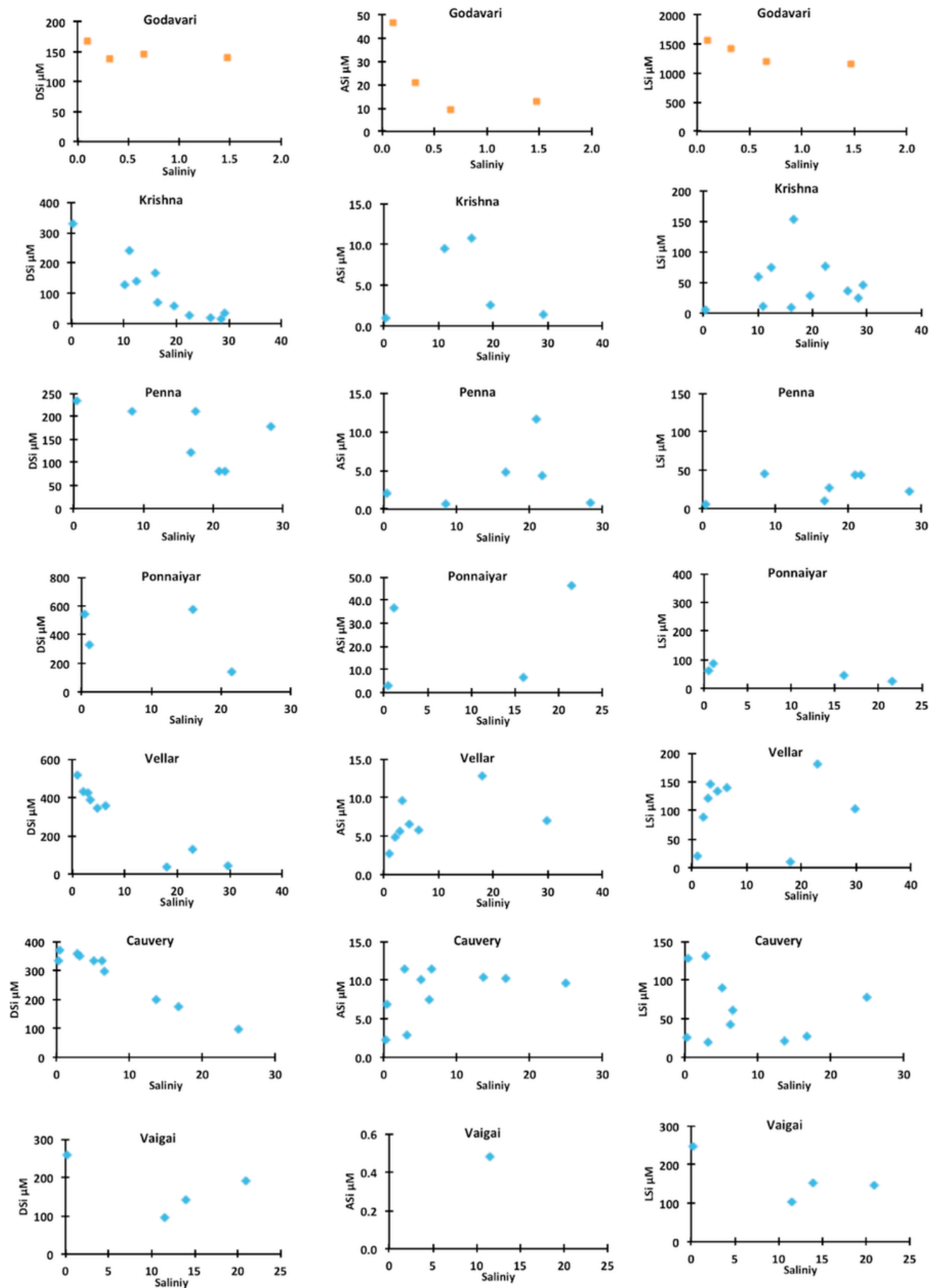

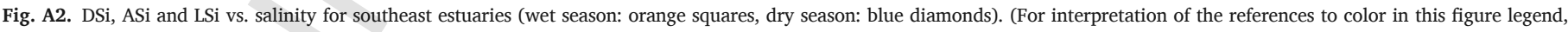
the reader is referred to the web version of this article.)

pogenic activities. Therefore, temporal monitoring of individual estuaries is necessary to better assess continuing changes to the Si cycle and its impact on the health of the estuarine and coastal ecosystems.

4) Our results show a strong seasonal effect on the variability of biogeochemical parameters along the salinity gradient and expose ma- jor differences among different estuaries. We extrapolate our data taking into account sampling coverage and non-conservativity within estuaries, to estimate DSi, ASi and LSi fluxes from Indian subcontinent respectively as $211 \pm 32,10 \pm 5,2028 \pm 317 \mathrm{Gmol}$ to the Bay of Bengal compared to $80 \pm 15,7 \pm 1$ and $1717 \pm 932 \mathrm{Gmol}$ to the Arabian Sea. 

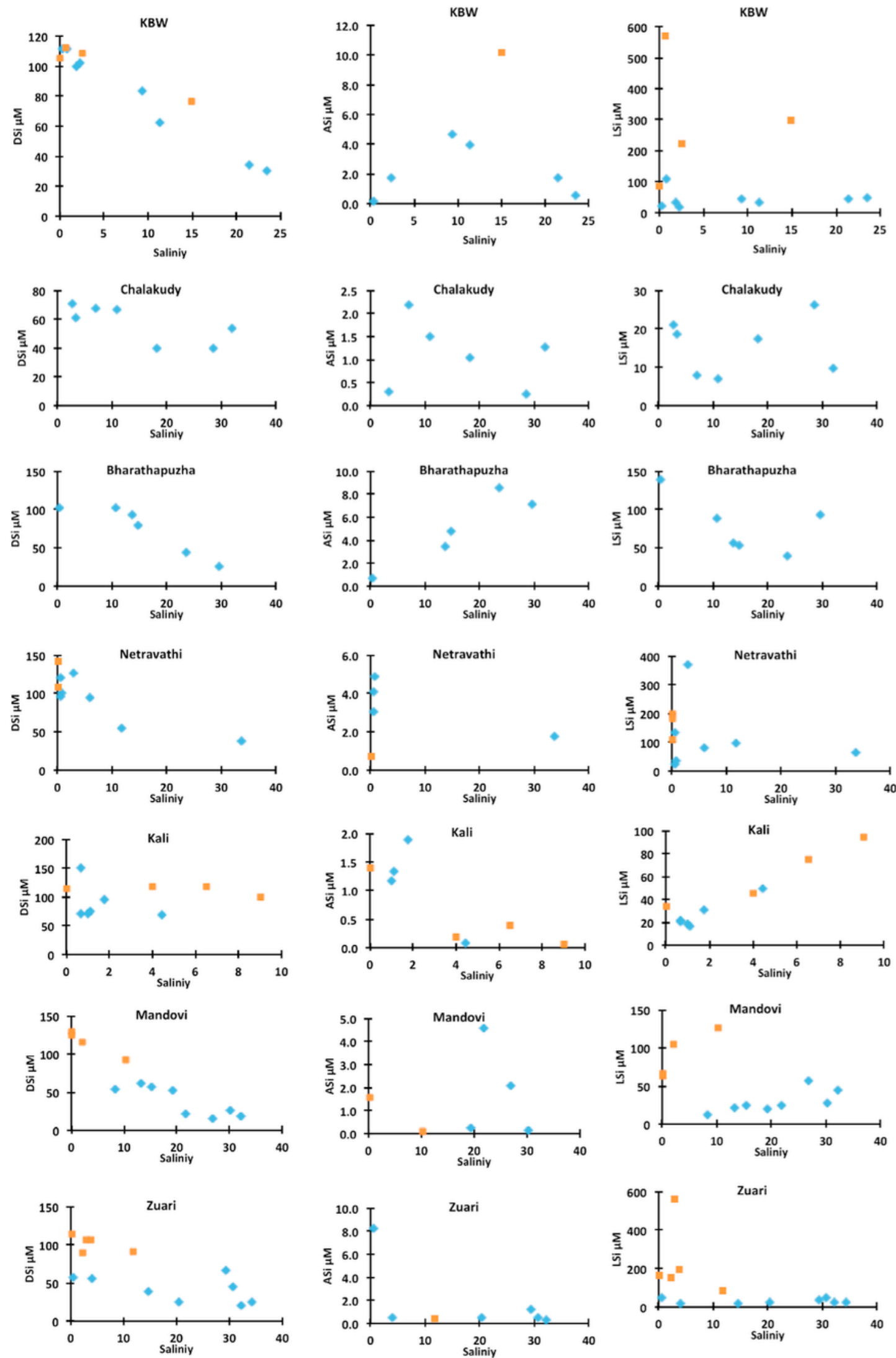

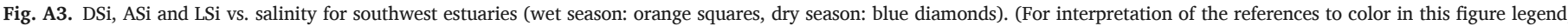
the reader is referred to the web version of this article.) 

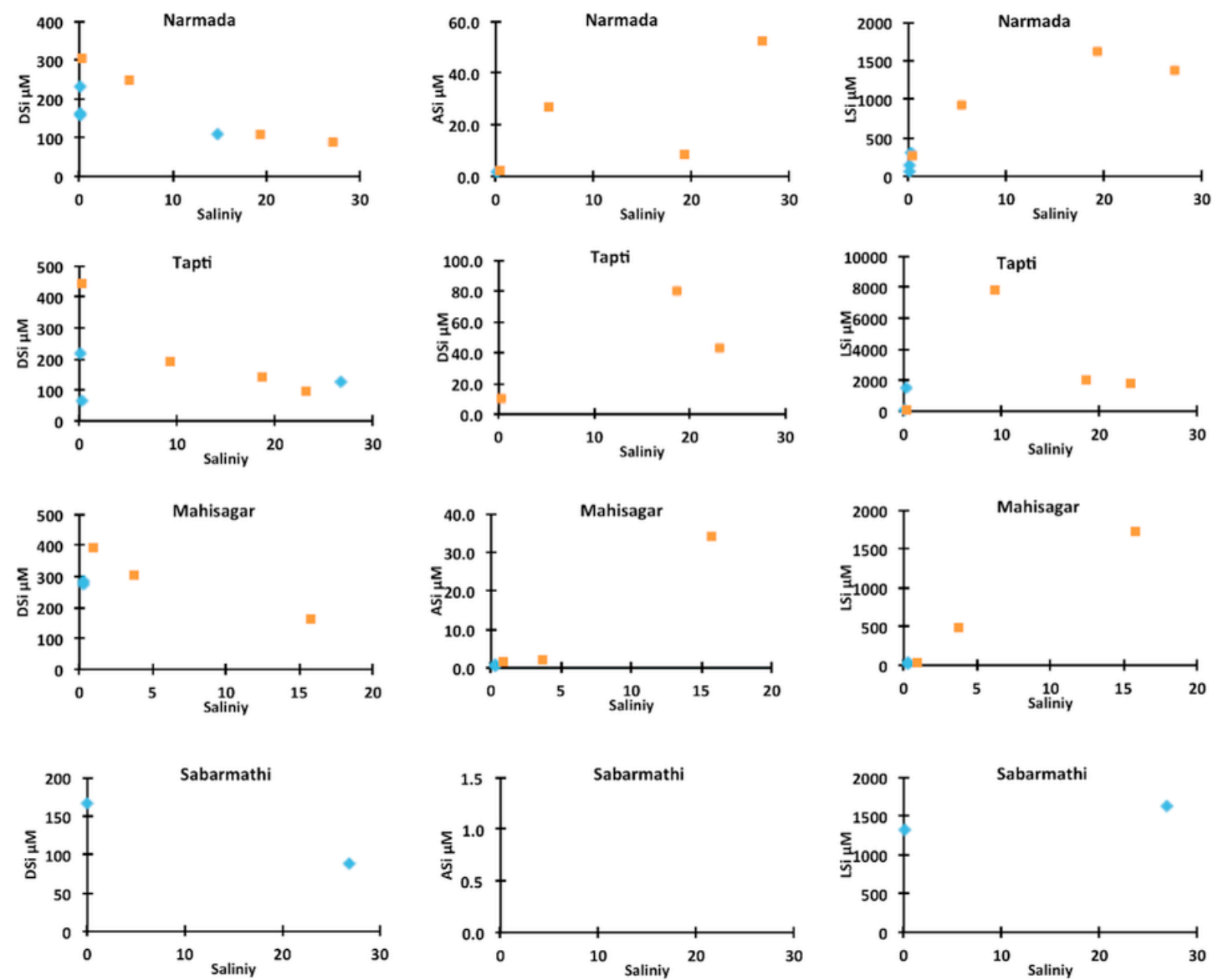

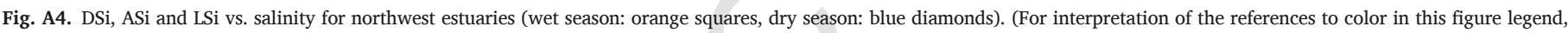
the reader is referred to the web version of this article.)

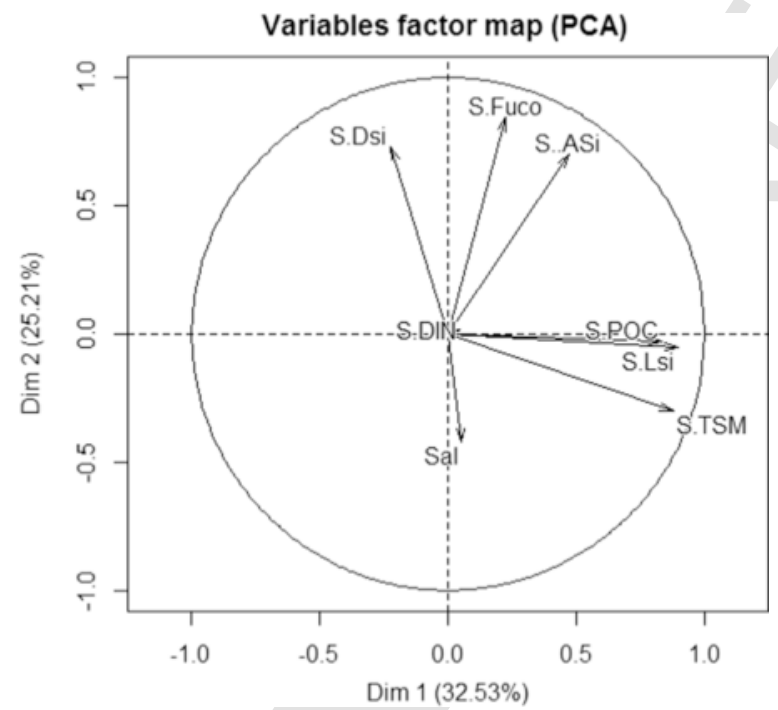

Fig. B1. PCA analysis on upper estuaries during dry period.

5) We show that the Si:N ratio was always above 1 , ( 1 being the ratio needed for diatoms growth) across the entire salinity range and across seasonal and spatial differences. This could in part explain the absence of eutrophication prevailing in the Indian estuaries and their adjoining coastal seas.

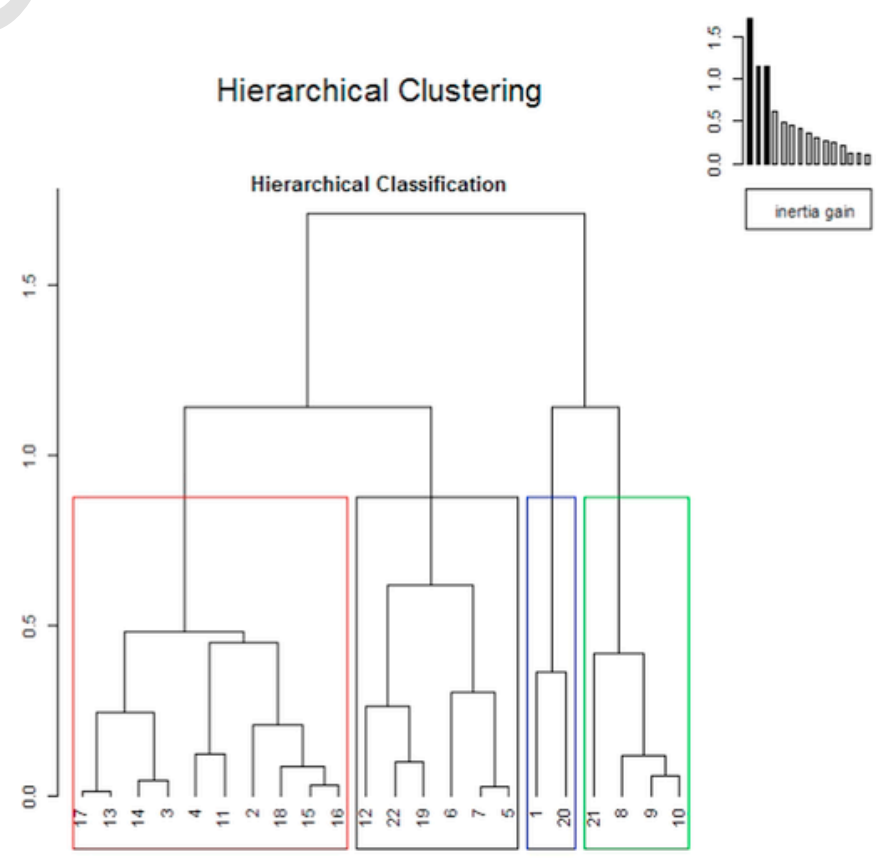

Fig. B2. Hierarchial clustering of PCA results on upper estuaries during dry period. 




Fig. B3. PCA analysis on lower estuaries during dry period.

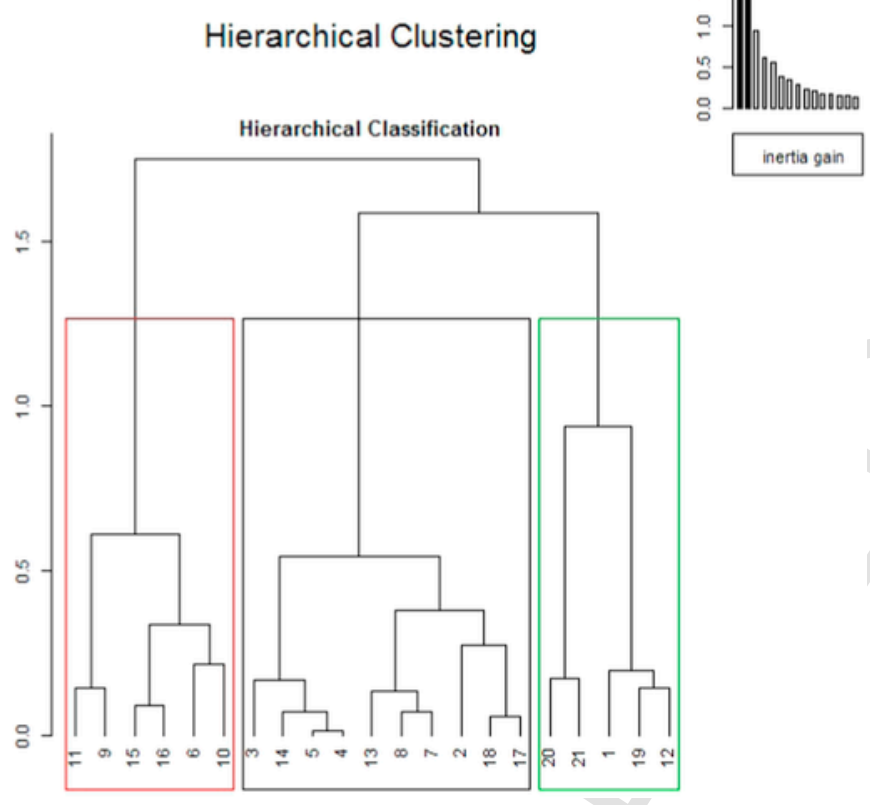

Fig. B4. Hierarchial clustering of PCA results on lower estuaries during dry period.

\section{Uncited references}

Commission et al. (2014); Government of India (2012); Sharma and Subramanian (2008); Struyf et al. (2006).

\section{Acknowledgements}

The research leading to these results has been mostly funded by the European Union Seventh Framework Program under grant agreement \#294146 (MuSiCC Marie Curie CIG) and from the French National INSU programme EC2CO-LEFE (project SINDIA funded by Actions CYBER and BIOHEFFECT). K.R. Mangalaa scholarship has been mainly provided by the Erasmus Mundus Action 2 of the European Union (GATE project), with additional support from the Scientific Department of French Embassy in India and, MuSiCC. The authors would like to

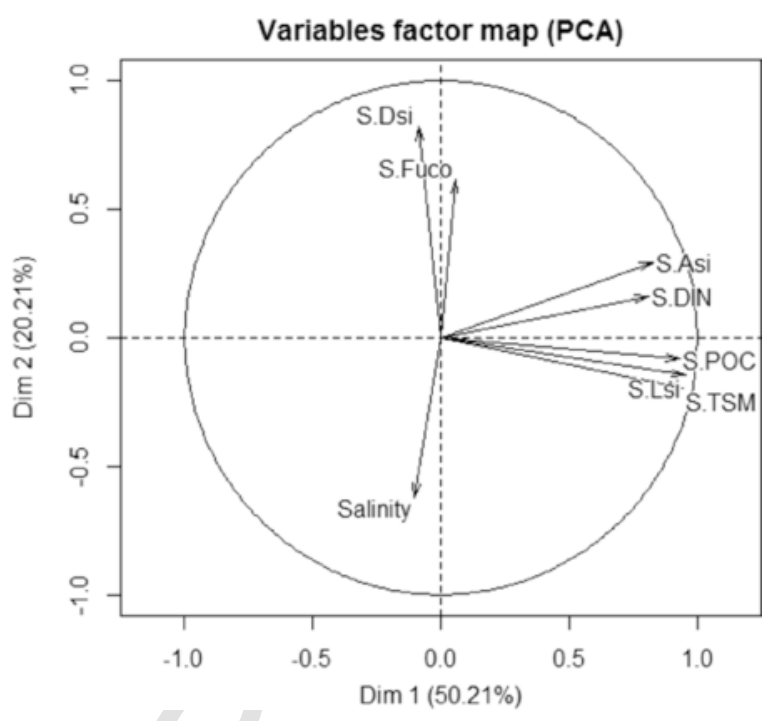

Fig. B5. PCA analysis on upper estuaries during wet period.

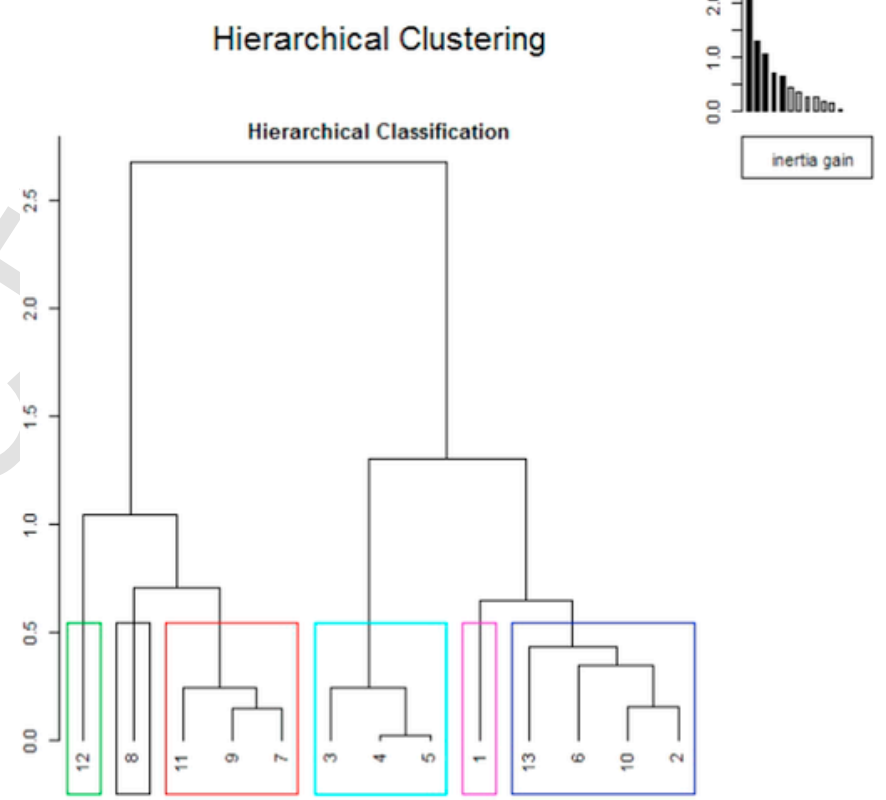

Fig. B6. Hierarchical clustering of PCA results on upper estuaries during wet period.

thank M. Benrahmoune (LOCEAN, CNRS) for managing the clean lab and performing colorimetric analyses. Special thanks to Bart Pattyn from Ranavision for extensive proofreading of the manuscript. We also thank the constructive and thorough comments from two anonymous reviewers, which helped in improving the paper.

\section{Appendix A. Individual samples data}

See Figs. A1-A4.

Appendix B. Additional PCA and clustering figures and tables

\section{B.1. Dry period}

See Figs. B1-B4. 




Fig. B7. PCA analysis on lower estuaries during wet period.

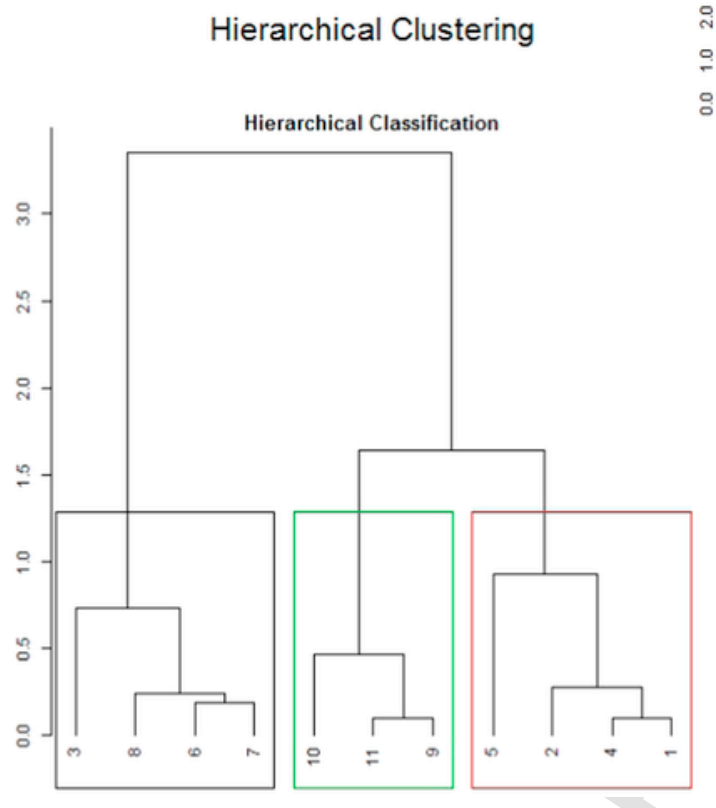

Fig. B8. Hierarchical clustering of PCA results on lower estuaries during wet period.

\section{B.2. Wet period}

See Figs. B5-B8.

B.3. Data used for PCA and clustering

See Tables B1-B4.

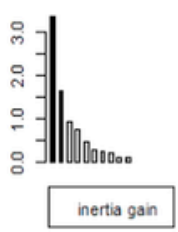

inertia gain 
Table B1

Upper estuaries - dry period.

\begin{tabular}{|c|c|c|c|c|c|c|c|c|c|}
\hline Ind.no & Estuary & Sal & DSi $(\mu \mathrm{M})$ & TSM (mg/l) & POC $(\mu \mathrm{M})$ & $\operatorname{DIN}(\mu \mathrm{M})$ & ASi $(\mu \mathrm{M})$ & LSi $(\mu \mathrm{M})$ & Fuco $(\mu \mathrm{g} / \mathrm{l})$ \\
\hline 1 & Haldia-Hal & 4.1 & 57 & 206 & 258 & 28 & 1.9 & 1280 & 0.3 \\
\hline 2 & Subernareka- Sub & 4.3 & 159 & 30 & 103 & 9 & 7.0 & 189 & 1.5 \\
\hline 3 & Mahanadi-Maha & 3.4 & 151 & 21 & 75 & 6 & 1.0 & 38 & 0.2 \\
\hline 4 & Vamsadhara-Vam & 1.8 & 368 & 13 & 65 & 3 & 3.9 & 74 & 0.4 \\
\hline 5 & Nagavalli-Nag & 0.5 & 399 & 9 & 47 & 13 & 3.7 & 26 & 2.2 \\
\hline 6 & Krishna-kri & 0.4 & 327 & 3 & 61 & 75 & 0.9 & 6 & NA \\
\hline 7 & Penna-Pen & 0.6 & 218 & 7 & 45 & 13 & 2.6 & 26 & 2.5 \\
\hline 8 & Ponnaiyar-Pon & 1.1 & 494 & 84 & 167 & 7 & 13.3 & 63 & 6.7 \\
\hline 9 & Cauvery-Cau & 2.3 & 348 & 21 & 98 & 8 & 6.7 & 79 & 5.3 \\
\hline 10 & Vellar-vel & 2.8 & 423 & 46 & 172 & 17 & 5.9 & 102 & 2.9 \\
\hline 11 & Ambullar-Amb & 4.2 & 317 & 17 & 95 & 7 & 2.5 & 40 & 0.2 \\
\hline 12 & Vaigai-Vai & 0.2 & 258 & 85 & 124 & 10 & 1.8 & 246 & 0.1 \\
\hline 13 & KBW & 1.3 & 106 & 66 & 51 & 18 & 1.6 & 45 & 0.8 \\
\hline 14 & Chalakudy-Cha & 3.0 & 66 & 31 & 56 & 6 & 1.1 & 20 & 0.2 \\
\hline 15 & Bharathapuzha-Bha & 1.8 & 99 & 45 & 84 & 8 & 2.1 & 95 & 1.3 \\
\hline 16 & Netravathi-Net & 1.2 & 110 & 30 & 74 & 5 & 3.9 & 141 & 1.6 \\
\hline 17 & Kali & 1.6 & 89 & 63 & 55 & 20 & 1.4 & 26 & 0.4 \\
\hline 18 & Zuari-Zua & 2.3 & 57 & 63 & 65 & 11 & 4.4 & 34 & 2.0 \\
\hline 19 & Narmada-Nar & 0.1 & 183 & 22 & NA & 34 & 2.3 & 171 & 0.7 \\
\hline 20 & Tapti-Tap & 0.2 & 142 & 288 & 916 & 23 & 2.7 & 772 & 1.3 \\
\hline 21 & Sabarmati-Sab & 0.0 & 166 & 84 & NA & 39 & 6.5 & 1330 & 5.2 \\
\hline 22 & Mahisagar-Mahi & 0.2 & 278 & 28 & NA & 82 & 0.7 & 42 & 0.8 \\
\hline
\end{tabular}

Table B2

Lower estuaries - dry period.

\begin{tabular}{|c|c|c|c|c|c|c|c|c|c|}
\hline Ind.no & Estuary & Sal & $\mathrm{DSi}(\mu \mathrm{M})$ & TSM (mg/l) & POC $(\mu \mathrm{M})$ & DIN $(\mu \mathrm{M})$ & $\mathrm{ASi}(\mu \mathrm{M})$ & LSi $(\mu \mathrm{M})$ & Fuco $(\mu \mathrm{g} / \mathrm{l})$ \\
\hline 1 & Haldia-Hal & 5.7 & 134 & 48 & 192 & 30 & 2.1 & 268 & 0.4 \\
\hline 2 & Baitharani-Bai & 17.5 & 37 & 56 & 135 & 10 & 1.4 & 207 & 0.7 \\
\hline 3 & Mahanadi-Maha & 9.3 & 74 & 14 & 52 & 6 & 0.9 & 61 & 0.4 \\
\hline 4 & Rushikulya-Rus & 20.4 & 63 & 27 & 57 & 7 & 1.4 & 54 & 0.4 \\
\hline 5 & Vamsadhara-Vam & 18.2 & 69 & 27 & 56 & 5 & 1.1 & 31 & 0.6 \\
\hline 6 & Nagavalli-Nag & 18.3 & 118 & 7 & 97 & 10 & 3.7 & 37 & 1.7 \\
\hline 7 & Krishna-kri & 17.4 & 102 & 58 & 52 & 17 & 4.0 & 57 & 1.3 \\
\hline 8 & Penna-Pen & 16.7 & 101 & 19 & 32 & 14 & 4.4 & 41 & 1.6 \\
\hline 9 & Ponnaiyar-Pon & 21.5 & 178 & 56 & 223 & 13 & 25.6 & 187 & 12.3 \\
\hline 10 & Cauvery-Cau & 12.5 & 233 & 25 & 89 & 5 & 10.5 & 44 & 5.1 \\
\hline 11 & Vellar-vel & 19.3 & 143 & 62 & 169 & 8 & 7.2 & 108 & 2.7 \\
\hline 12 & Vaigai-Vai & 15.4 & 142 & 60 & 124 & 10 & 1.4 & 134 & 0.5 \\
\hline 13 & KBW & 15.5 & 53 & 86 & 51 & 8 & 2.7 & 42 & 2.8 \\
\hline 14 & Chalakudy-Cha & 19.3 & 53 & 11 & 49 & 7 & 1.2 & 14 & 0.6 \\
\hline 15 & Bharathapuzha-Bha & 19.8 & 49 & 19 & 111 & 2 & 6.8 & 62 & 0.9 \\
\hline 16 & Netravathi-Net & 17.1 & 63 & 27 & 75 & 3 & 5.0 & 81 & 4.1 \\
\hline 17 & Zuari-Zua & 26.9 & 37 & 46 & 67 & 10 & 1.5 & 29 & 1.4 \\
\hline 18 & Mandovi-Man & 20.9 & 38 & 42 & 45 & 12 & 2.0 & 29 & 2.4 \\
\hline 19 & Narmada-Nar & 14.7 & 108 & NA & NA & 46 & 1.2 & NA & NA \\
\hline 20 & Tapti-Tap & 26.7 & 125 & 49 & NA & 42 & 2.5 & 2635 & 0.9 \\
\hline 21 & Sabarmati-Sab & 26.9 & 89 & 334 & NA & 60 & 1.4 & 1633 & NA \\
\hline
\end{tabular}

Table B3

Upper estuaries - wet period.

\begin{tabular}{|c|c|c|c|c|c|c|c|c|c|}
\hline Ind.no & Estuary & Sal & $\mathrm{DSi}(\mu \mathrm{M})$ & TSM (mg/l) & POC $(\mu \mathrm{M})$ & DIN $(\mu \mathrm{M})$ & ASi $(\mu \mathrm{M})$ & LSi $(\mu \mathrm{M})$ & Fuco $(\mu \mathrm{g} / \mathrm{l})$ \\
\hline 1 & Haldia-Hal & 2.8 & 113 & 617 & 131 & 34 & 5.9 & 2241 & 0.4 \\
\hline 2 & Subernarekha-Sub & 2.0 & 181 & 74 & 51 & 11 & 15.7 & 526 & 0.4 \\
\hline 3 & Rushikulya-Rus & 0.1 & 242 & 278 & 91 & 35 & 62.8 & 2001 & 0.1 \\
\hline 4 & Mahanadi-Maha & 0.1 & 149 & 209 & 68 & 40 & 32.6 & 1442 & NA \\
\hline 5 & Godavari-God & 0.6 & 147 & 200 & 76 & 54 & 22.3 & 1338 & NA \\
\hline 6 & KBW & 1.1 & 109 & 46 & 105 & 45 & 5.5 & 293 & 0.4 \\
\hline 7 & Netravathi-Net & 0.1 & 130 & 30 & 29 & 24 & 2.6 & 164 & 0.5 \\
\hline 8 & Kali & 2.0 & 116 & 9 & 17 & 5 & 0.8 & 39 & 0.1 \\
\hline 9 & Mandovi-Man & 0.7 & 123 & 17 & 21 & 18 & 1.2 & 78 & 0.2 \\
\hline 10 & Zuari-Zua & 2.3 & 104 & 46 & 38 & 21 & 5.4 & 270 & 0.5 \\
\hline 11 & Narmada-Nar & 0.4 & 305 & 42 & 27 & 13 & 2.5 & 266 & 0.3 \\
\hline 12 & Tapti-Tap & 0.3 & 443 & 13 & 36 & 18 & 9.8 & 57 & 1.7 \\
\hline 13 & Mahisagar-Mahi & 2.3 & 347 & 42 & 34 & 32 & 1.8 & 262 & 0.5 \\
\hline
\end{tabular}


Table B4

Lower estuaries - wet period.

\begin{tabular}{|c|c|c|c|c|c|c|c|c|c|}
\hline Ind.no & Estuary & Sal & DSi $(\mu \mathrm{M})$ & TSM (mg/l) & POC $(\mu \mathrm{M})$ & DIN $(\mu \mathrm{M})$ & ASi $(\mu \mathrm{M})$ & LSi $(\mu \mathrm{M})$ & Fuco $(\mu \mathrm{g} / \mathrm{l})$ \\
\hline 1 & Haldia-Hal & 6.1 & 112 & 414 & NA & 14 & 17.6 & 1582 & 0.5 \\
\hline 2 & Subernarekha-Sub & 10.3 & 119 & 60 & 31 & 26 & 9.5 & 360 & 0.9 \\
\hline 3 & Rushikulya-Rus & 14.0 & 146 & 28 & 16 & 14 & 4.6 & 138 & 0.5 \\
\hline 4 & Mahanadi-Maha & 7.6 & 105 & 137 & NA & 5 & 9.9 & 796 & NA \\
\hline 5 & KBW & 14.9 & 77 & 62 & 84 & 16 & 10.1 & 297 & 1.4 \\
\hline 6 & Kali & 7.8 & 109 & 21 & 25 & 7 & 0.2 & 85 & 0.2 \\
\hline 7 & Mandovi-Man & 10.3 & 92 & 29 & 34 & 7 & 0.1 & 127 & NA \\
\hline 8 & Zuari-Zua & 11.8 & 91 & 22 & 31 & 1 & 0.4 & 85 & 0.3 \\
\hline 9 & Narmada-Nar & 19.4 & 149 & 431 & 51 & 44 & 29.4 & 1299 & 0.5 \\
\hline 10 & Tapti-Tap & 17.0 & 145 & 596 & NA & 53 & 61.4 & 3881 & 2.3 \\
\hline 11 & Mahisagar-Mahi & 15.8 & 162 & 368 & NA & 53 & 34.0 & 1737 & 0.4 \\
\hline
\end{tabular}

\section{References}

Admiraal, W., Breugem, P., Jacobs, D.M.L.H.a., Steveninck, E.D., 1990. Fixation of dissolved silicate and sedimentation of biogenic silicate in the lower river Rhine during diatom blooms. Biogeochemistry 9, 175-185.

Aigars, J., Jurgensone, I., Jansons, M., Dynamics of silica and phytoplankton population under altered conditions of river flow in the Daugava River, Latvia. Est. J. Ecol. 63, 217 (2014).Anderson, G.F., Silica, diatoms and a freshwater productivity maximum in Atlantic Coastal Plain estuaries, Chesapeake Bay. Estuar. Coast. Shelf Sci. 22, 183-197 (1986).Ansotegui, A., The use of pigment signatures to assess phytoplankton assemblage structure in estuarine waters. Estuar. Coast. Shelf Sci. 52, 689-703 (2001).Attri, S.D., Tyagi, A., 2010. Climate Profile of India. Gov. India Minist. Earth Sci., 129. At 〈http:// www.imd.gov.in/doc/climate_profile.pdf).Barão, L., Vandevenne, Floor, Clymans, Wim, Frings, Patrick, Ragueneau, Olivier, Meire, Patrick, Conley, Daniel J., Struyf, Eric, Alkaline-extractable silicon from land to ocean: a challenge for biogenic silicon determination. Limnol. Oceanogr. Methods 13, 329-344 (2015).Berner, R.A., Weathering, plants, and the long-term carbon cycle. Geochim. Cosmochim. Acta 56 (8), 3225-3231

(1992).Bootsma, H.A., Hecky, R.E., Johnson, T.C., Kling, H.J., Mwita, J., Inputs, outputs, and internal cycling of silica in a large, tropical lake. J. Gt. Lakes Res. 29, 121-138 (2003).Brzezinski, M.A., The Si:C:N ratio of marine diatoms: interspecific variability and the effect of some environmental variables. J. Phycol. 21, 347-357 (1985).Carbonnel, V., Vanderborght, J.P., Lionard, M., Chou, L., Diatoms, silicic acid and biogenic silica dynamics along the salinity gradient of the Scheldt estuary (Belgium/The Netherlands). Biogeochemistry 113, 657-682 (2013).Cary, L., Alexandre, A., Meunier, J.D., Boeglin, J.L. Braun, J.J., Contribution of phytoliths to the suspended load of biogenic silica in the Ny ong basin rivers (Cameroon). Biogeochemistry 74, 101-114 (2005).Central Water Commission Report, 2009. National Register of Large Dams - 2009.Chou, L., Wollast, R., Estuarine silicon dynamics. In: Ittekkot, V., Unger, D., Humborg, C., Tac An, N. (Eds.), 2006. The Silicon Cycle. Human Perturbations and Impacts on Aquatic Systems Island Press, Washington, Covelo, London, pp. 93-120Scope 66.Clymans, W., Govers, G., Van Wesemael, B., Meire, P., Struyf, E., Amorphous silica analysis in terrestrial runoff samples. Geoderma 167-168, 228-235 (2011).Commission, C.W., Remote, N., Centre, S., 2014. Watershed Atlas.Conley, D.J., Riverine contribution of biogenic silica to the oceanic silica budget. Limnol. Oceanogr. 42, 774-777 (1997).Conley, D.J., Terrestrial ecosystems and the global biogeochemical silica cycle. Glob. Biogeochem. Cycles 16, 1-8 (2002).Conley, D.J., Schelske, C.L., Stoermer, E.F., Modification of the biogeochemical cycle of silica with eutrophication. Mar. Ecol. Prog. Ser. 101, 179-192 (1993).

Conley D.J. Likens Gene E. Buso Donald C. Saccone Loredana Bailey Scott W. Johnson Chris E. 2008. Deforestation causes increased dissolved silicate losses in the Hubbard Brook experimental forest Glob. Change Biol. 14 2548-2554

Conley, D.J., 1998. An Interlaboratory Comparison for the Measurement of Biogenic Silica in Sediments, pp. 39-48.

Delvaux, C., Cardinal, D., Carbonnel, V., Chou, L., Hughes, H.J., André, L., 2013. Controls on riverine $830 \mathrm{Si}$ signatures in a temperate watershed under high anthropogenic pressure (Scheldt — Belgium). J. Mar. Syst. 1-12

Ducklow, H.W., Steinberg, D.K., Buesseler, K.O., Upper ocean carbon export and the biological pump. Oceanography 14, 50-58 (2001).Dunne, T., Rates of chemical denudation of silicate rocks in tropical catchments. Nature 274, 244-246 (1978).Durga

Bharathi, 2014. Variability in Composition and Diversity of Phytoplankton in the Indian Estuaries and Coastal Bay of Bengal (Ph.D. thesis).Dür, H.H., Meybeck, M., Hartmann, J., Laruelle, G.G., Roubeix, V., Global spatial distribution of natural riverine silica inputs to the coastal zone. Biogeosciences 8, 597-620 (2011).Friedl, G., Teodoru, C., Wehrli, B., Is the Iron Gate I reservoir on the Danube River a sink for dissolved silica?. Biogeochemistry $68,21-32$ (2004).

Frings P.J. Clymans W. Conley D.J. 2014. Amorphous silica transport in the Ganges basin: implications for Si delivery to the oceans Procedia Earth Planet. Sci. 10 271-274

Frings, P.J., Clymans, Wim, Fontorbe, Guillaume, Gray, William, Chakrapani, Govind J., Conley, Daniel J., De La Rocha, Christina, 2015. Silicate weathering in the Ganges alluvial plain. Earth Planet. Sci. Lett. 427, 136-148.

Garnier, J., Beusen, A., Thieu, V., Billen, G., Bouwman, L., N:P:Si nutrient export ratios and ecological consequences in coastal seas evaluated by the ICEP approach. Glob. Biogeochem. Cycles 24, 1-12 (2010)(GB0A05).Government of India, 2012. State of Indian Agriculture, 247. 〈http://agricoop.nic.in/sia111213312.pdf).Grasshoff, K., Kremling, K., Ehrhardt, M., 1999. Methods of Seawater Analysis, 3rd Edison completely Revised and Extended edition, Wiley-VCH, ISBN 3-527-29589-5.Gupta, Garuda V.M., Sarma, Vongala
V., Biogenic silica in the Bay of Bengal. Oceanol. Acta 20 (3), 493-500 (1997).Gurumurthy, G.P., Balakrishna, K., Riotte, Jean Braun, Audry, Jean-Jacques, Stéphane Shankar, H.N., Udaya Manjunatha, B.R., Controls on intense silicate weathering in a tropical river, southwestern India. Chem. Geol. 300-301, 61-69 (2012).Heiskanen, A.S. Keck, A., Distribution and sinking rates of phytoplankton, detritus, and particulate biogenic silica in the Laptev Sea and Lena River (Arctic Siberia). Mar. Chem. 53, 229-245 (1996).Heukelem, Van L., Thomas, C., Computer-assisted high-performance liquid chromatography method development with applications to the isolation and analysis of phytoplankton pigments. J. Chromatogr. A 910, 31-49 (2001).Howarth, Robert, Chan, Francis, Conley, Daniel J., Garnier, Josette, Doney, Scott C., Marino Roxanne Billen, Gilles, Coupled biogeochemical cycles: eutrophication and hypoxia in temperate estuaries and coastal marine ecosystems. Front. Ecol. Environ. 9, 18-26 (2011).Hughes, H.J., Sondag, Francis, Cocquyt, Christine, Laraque, Alain, Pandi, Albert, André, Luc, Cardinal, Damien, Effect of seasonal biogenic silica variations on dissolved silicon fluxes and isotopic signatures in the Congo River. Limnol. Oceanogr. 56, 551-561 (2011).Hughes, H.J., Bouillon, S., André, L., Cardinal, D., The effects of weathering variability and anthropogenic pressures upon silicon cycling in an intertropical watershed (Tana River, Kenya). Chem. Geol. 308-309, 18-25 (2012).Hughes, H.J., Sondag, F., Santos, R.V., André, L., Cardinal, D., The riverine silicon isotope composition of the Amazon Basin. Geochim. Cosmochim. Acta 121, 637-651 (2013).Humborg, C., Pastuszak, M., Aigars Juris, Siegmund, H., Morth, C.-M., Ittekkot, V., Decreased silica land-sea fluxes through damming in the Baltic Sea catchment - significance of particle trapping and hydrological alterations. Biogeochemistry 77, 265-281 (2006).Ittekkot, V., Nair, R.R., Honjo, S., Ramaswamy, V., Bartsch, M., Manganini, S., Desai, B.N., Enhanced particle fluxes in Bay of Bengal induced by injection of fresh water. Nature 351, 385-387 (1991).Krishna, M.S., Prasad, M.H.K., Rao, D.B., Viswanadham, R., Sarma, V.V.S.S., Reddy, N.P.C., Export of dissolved inorganic nutrients to the northern Indian Ocean from the Indian monsoonal rivers during discharge period. Geochim. Cosmochim. Acta 172, 430-443 (2016).Laruelle, G.G. Roubeix, V., Sferratore, A., Brodherr, B., Ciuffa, D., Conley, D.J., Dürr, H.H., Garnier, J., Lancelot, C., Le Thi Phuong, Q., Meunier, J.-D., Meybeck, M., Michalopoulos, P., Moriceau, B., Ní Longphuirt, S., Loucaides, S., Papush, L., Presti, M., Ragueneau, O., Regnier, P., Saccone, L., Slomp, C.P., Spiteri, C., Van Cappellen, P., Anthropogenic perturbations of the silicon cycle at the global scale: key role of the land-ocean transition. Glob. Biogeochem. Cycles 23, 1-17 (2009).Lehtimäki, M., Tallberg, P., Siipola, V., Seasonal dynamics of amorphous silica in vantaa river estuary. Silicon 5, 35-51 (2013).Li, M., Xu, K., Watanabe, M., Chen, Z., Long-term variations in dissolved silicate, nitrogen, and phosphorus flux from the Yangtze River into the East China Sea and impacts on estuarine ecosystem. Estuar. Coast. Shelf Sci. 71, 3-12 (2007).Liu, S.M., Hong, G.-H., Ye, X.W., Zhang, J., Jiang, X.L., Nutrient budgets for large Chinese estuaries and embayment. Biogeosci.Discuss. 6, 391-435 (2009).Lu, C.A.O., Sumei, L.I.U., Jingling, R.E.N., Seasonal variations of particulate silicon in the Changiiang (Yangtze River) estuary and its adjacent area. Acta Oceanol. Sin. 32, 1-10 (2013).Meunier, J.D., Riotte, J., Braun, J.J., Sekhar, M., Chalié, F., Barboni, D., Saccone, L., Controls of DSi in streams and reservoirs along the Kaveri River, South India. Sci. Total Environ. 502, 103-113 (2015).Middelburg, J.J., Herman, P.M.J., Organic matter processing in tidal estuaries. Mar. Chem. 106, 127-147 (2007).Nair, R.R., Ittekkot, V., Managanini, S.J., Ramaswamy, V., Hakke, B., Degens, E.T., Desai, B.N., Honjo, S., Increased particle flux to the deep ocean related to monsoon. Nature 338, 749-751 (1989).Naqvi, S.W.A., Moffett, J.W., Gauns, M.U., Narvekar, P.V., Pratihary, A.K., Naik, H., Shenoy, D.M., Jayakumar, D.A., Goepfert, T.J., Patra, P.K., Al-Azri, A., Ahmed, S.I., The Arabian Sea as a high-nutrient, low-chlorophyl region during the late Southwest Monsoon. Biogeosciences 7 (7), 2091-2100. (2010)https://doi.org/10.5194/bg-7-2091-2010.

Nayak G.N. Hanamgond P.T. 2010. India Encycl. Coast. Landf. 2010 1065-1070

Nelson, D.M., Tréguer, P., Brzezinski, M.A., Leynaert, A., Quéguiner, B., 1995. Production and dissolution of biogenic silica in the ocean: revised global estimates, comparison with regional data and relationship to biogenic sedimentation. Glob. Biogeochem. Cycles 9, 359-372.

Ragueneau O. Treguer P. Leynaert A. Anderson R.F. Brzezinski M.A. De Master D.J. 2000 A review of the Si cycle in the modern ocean: recent progress and missing gaps in the application of biogenic opal as a paleoproductivity proxy Glob. Planet. Change 26 317-365

Ragueneau, Olivier, Savoye, Nicolas, Del Amo, Yolanda, Cotten, Jo, Benoît, Tardiveau, Leynaert, Aude, Del, Yolanda, Cotten, Jo, 2005. A new method for the measurement of biogenic silica in suspended matter of coastal waters: using Si:Al ratios to correct for the mineral interference. Cont. Shelf Res. 25, 697-710.

Raimonet, M., Andrieux-Loyer, F., Ragueneau, O., Michaud, E., Kerouel, R., Philippon, X., Nonent, M., Mémery, L., Strong gradient of benthic biogeochemical processes along a macrotidal temperate estuary: focus on P and Si cycles. Biogeochemistry 2013.Ran, Xi- 
angBin, Che, Hong, Zang, JiaYe, Yu, Yong Gui, Liu, Sen, Zheng, Li.Li, Variability in the composition and export of silica in the Huanghe River Basin. Sci. China Earth Sci.

2015.Rao, G.D., Sarma, V.V.S.S., Contribution of N2O emissions to the atmosphere from Indian monsoonal estuaries. Tellus, Ser. B Chem. Phys. Meteorol. 1, 1-9 (2013).Sarma, V.V.S.S., Gupta, S.N.M., Babu, P.V.R., Acharya, T., Harikrishnachari, N., Vishnuvardhan, K., Rao, N.S., Reddy, N.P.C., Sarma, V.V., Sadhuram, Y., Murty, T.V.R., Kumar, M.D., Influence of river discharge on plankton metabolic rates in the tropical monsoon driven Godavari estuary, India. Estuar. Coast. Shelf Sci. 85, 515-524 (2009).

Sarma V.V.S.S. Viswanadham R. Rao G.D. Prasad V.R. Kumar B.S.K. Naidu S.a. Kumar N.a. Rao D.B. Sridevi T. Krishna M.S. Reddy N.P.C. Sadhuram Y. Murty T.V.R. 2012. Carbon dioxide emissions from Indian monsoonal estuaries Geophys. Res. Lett. 39

Sarma, V.V.S.S., Sridevi, B., Maneesha, K., Sridevi, T., Naidu, S.A., Prasad, V.R., Venkataramana, V., Acharya, T., Bharati, M.D., Subbaiah, C.V., Kiran, B.S., Reddy, N.P.C., Sarma, V.V., Sadhuram, Y., Murty, T.V.R., 2013. Impact of atmospheric and physical forcing on biogeochemical cycling of dissolved oxygen and nutrients in the coastal Bay of Bengal. J. Oceanogr. 69 (2), 229-243. https://doi.org/10.1007/ s10872-012-0168-y.

Sarma, V.V.S.S., Krishna, M.S., Prasad, V.R., Kumar, B.S.K., Naidu, S.A., Rao, G.D., Viswanadham, R., Sridevi, T., Kumar, P.P., Reddy, N.P.C., 2014. Distribution and Sources of Particulate Organic Matter in the Indian Monsoonal Estuaries during Monsoon, 119, pp. 1-17.

Schoelhamer, D.H., 2001. Influence of salinity, bottom topography, and tides on locations of estuarine turbidity maxima in northern San Francisco Bay. In: McAnally, W.H., Mehta, A.J. (Eds.), Coastal and Estuarine Fine Sediment Transport Processes. Elsevier Science B.V., pp. 343-357.

Sharma, S.K., Subramanian, V., Hydrochemistry of the Narmada and Tapti Rivers, India. Hydrol. Process. 22, 3444-3455 (2008).Shynu, R., Purnachandra Rao, V., Sarma,

V.V.S.S., Kessarkar, P.M., Mani Murali, R., Sources and fate of organic matter in suspended and bottom sediments of the Mandovi and Zuari estuaries, western India. Curr. Sci. 108 (2), 226-238 (2015).Soman, M.K., Kumar, K.K., Some aspects of daily rainfall distribution over India during the south-west monsoon season. Int. J. Climatol. 10, 299-311 (1990).Sridevi, B., Sarma, V.V.S.S., Murty, T.V.R., Sadhuram, Y., Reddy, N.P.C., Vijayakumar, K., Raju, N.S.N., Jawahar Kumar, C.H., Raju, Y.S.N., Luis, R., Kumar, M.D., Prasad, K.V.S.R., Variability in stratification and flushing times of the Gautami-Godavari estuary, India. J. Earth Syst. Sci. 124, 993-1003 (2015).Struyf, E., Van Damme, S., Gribsholt, B., Middelburg, J.J., Meire, P., Biogenic silica in tidal freshwater marsh sediments and vegetation (Schelde estuary, Belgium). Mar. Ecol. Prog. Ser. 303, 51-60 (2005).Struyf, E., Dausse, A., Van Damme, S., Bal, K., Gribsholt, B., Boschker, H.T.S., Middelburg, J.J., Meire, P., Tidal marshes and biogenic silica recycling at the land-sea interface. Limnol. Oceanogr. 51 (2), 838-846. (2006)https://doi.org/10.4319/lo.2006.51. 2.0838.Struyf, E., Smis, Adriaan, Van Damme, Stefan, Garnier, Josette, Govers, Gerard, Van Wesemael, Bas, Conley, Daniel J., Batelaan, Okke, Frot, Elisabeth, Clymans, Wim, Vandevenne, Floor, Lancelot, Christiane, Goos, Peter, Meire, Patrick, Continental historical land use change has lowered terrestrial silica mobilization. Nat. Commun. 1, 129. (2010)https://doi.org/10.1038/ncomms1128.Subramanian, V., Ittekkot, V., Unger, D., Madhavan, N., Silicate weathering in South Asian tropical river basins. In: Ittekkot, V., Uner, D., Humborg, C.H., Tac An, N. (Eds.), 2006. The Silicon Cycle, Human Perturbations and Impacts on Aquatic System. Island Press, pp. 3-12(SCOPE Report 66).Suja, S., Kessarkar, P.M., Shynu, R., Rao, V.P., Fernandes, L.L., Spatial distribution of suspended particulate matter in the Mandovi and Zuari estuaries: inferences on the estuarine turbidity maximum. Curr. Sci. 110 (7), 1165-1168 (2016).Sun, X., Andersson, P.S., Humborg, C., Pastuszak, M., Mörth, C.M., Silicon isotope enrichment in diatoms during nutrient-limited blooms in a eutrophied river system. J. Geochem. Explor. 132, 173-180 (2013).Tréguer, P., Nelson, D.M., Van Bennekom, A.J., Demaster, D.J., Leynaert, A., Quéguiner, B., The silica balance in the world ocean: a re-estimate. Science 268, 375-379 (1995).Tréguer, P.J., De La Rocha, C.L., The world ocean silica cycle. Ann. Rev. Mar. Sci. 5, 477-501 (2013).Vijith, V., Sundar, D., Shetye, S.R., Time-dependence of salinity in monsoonal estuaries. Estuar. Coast. Shelf Sci. 85, 601-608 (2009).Wedepohl, K.H., Ingerson lecture the composition of the continental crust. Geochim. Cosmochim. Acta 59, 1217-1232 (1995).Wu, J.T., Chou, T.L., Silicate as the limiting nutrient for phytoplankton in a subtropical eutrophic estuary of Taiwan. Estuar. Coast. Shelf Sci. 58, 155-162 (2003).Wysocki, L.A., Bianchi, T.S., Powell, R.T., Reuss, N., Spatial variability in the coupling of organic carbon, nutrients, and phytoplankton pigments in surface waters and sediments of the Mississippi River plume. Estuar. Coast. Shelf Sci. 69, 47-63 (2006).Xue, Jianhong, Lee, Cindy, Wakeham, Stuart G., Armstrong, Robert A., Using principal components analysis (PCA) with cluster analysis to study the organic geochemistry of sinking particles in the ocean. Org. Geochem. 42, 356-367 (2011).Zhang, A.Y., Zhang, J., Hu, J., Zhang, R.F., School, G.S.Z., J. Geophys. Res. Oceans 1-16 (2015).Zhu, Z.-Y., Ng, Wai-Man, Liu, Su-Mei, Zhang, Jing, Chen, Jay-Chung, Wu, Ying, Estuarine phytoplankton dynamics and shift of limiting factors: a study in the Changjiang (Yangtze River) Estuary and adjacent area. Estuar. Coast. Shelf Sci. 84, 393-401 (2009). 